\title{
Phosphatidylinositol 3-kinase signaling in proliferating cells maintains an anti-apoptotic transcriptional program mediated by inhibition of FOXO and non-canonical activation of $N F \kappa B$ transcription factors
} Jolyon Terragni ${ }^{\dagger 1}$, Julie R Graham ${ }^{\dagger 1}$, Kenneth W Adams ${ }^{1,2}$,
Michael E Schaffer ${ }^{1,3}$, John W Tullai ${ }^{1}$ and Geoffrey M Cooper*1

Address: ${ }^{1}$ Department of Biology, Boston University, Boston MA 02215, USA, ${ }^{2}$ Current Address: Alzheimer's Disease Research Center, Massachusetts General Hospital, Charlestown, MA 02129, USA and ${ }^{3}$ Current Address: Pfizer, Inc., Research Technology Center, 620 Memorial Drive, Cambridge, MA 02139, USA

Email: Jolyon Terragni - jolyon@bu.edu; Julie R Graham - jrgraham@bu.edu; Kenneth W Adams - kwadams@partners.org; Michael E Schaffer - Michael.Schaffer@pfizer.com; John W Tullai - jtullai@bu.edu; Geoffrey M Cooper* - gmcooper@bu.edu

* Corresponding author †Equal contributors

Published: 28 January 2008

BMC Cell Biology 2008, 9:6 doi:10.1186/1471-2121-9-6

This article is available from: http://www.biomedcentral.com/|47|-2/2I/9/6

(c) 2008 Terragni et al; licensee BioMed Central Ltd.

This is an Open Access article distributed under the terms of the Creative Commons Attribution License (http://creativecommons.org/licenses/by/2.0), which permits unrestricted use, distribution, and reproduction in any medium, provided the original work is properly cited.
Received: 17 August 2007

Accepted: 28 january 2008

\begin{abstract}
Background: Phosphatidylinositol (PI) 3-kinase is activated by a variety of growth factor receptors and the $\mathrm{PI} 3$ kinase/Akt signaling pathway is a key regulator of cell proliferation and survival. The downstream targets of PI 3kinase/Akt signaling include direct regulators of cell cycle progression and apoptosis as well as a number of transcription factors. Growth factor stimulation of quiescent cells leads to robust activation of PI 3-kinase, induction of immediate-early genes, and re-entry into the cell cycle. A lower level of PI 3-kinase signaling is also required for the proliferation and survival of cells maintained in the presence of growth factors, but the gene expression program controlled by PI 3-kinase signaling in proliferating cells has not been elucidated.

Results: We used microarray analyses to characterize the changes in gene expression resulting from inhibition of PI 3-kinase in proliferating cells. The genes regulated by inhibition of PI 3-kinase in proliferating cells were distinct from genes induced by growth factor stimulation of quiescent cells and highly enriched in genes that regulate programmed cell death. Computational analyses followed by chromatin immunoprecipitations demonstrated FOXO binding to both previously known and novel sites in promoter regions of approximately one-third of the up-regulated genes, consistent with activation of FOXOI and FOXO3a in response to inhibition of PI 3-kinase. NFKB binding sites were similarly identified in promoter regions of over one-third of the downregulated genes. RelB was constitutively bound to promoter regions in cells maintained in serum, however binding decreased following PI 3-kinase inhibition, indicating that PI 3-kinase signaling activates NFKB via the non-canonical pathway in proliferating cells. Approximately $70 \%$ of the genes targeted by FOXO and $\mathrm{NF} \kappa \mathrm{B}$ regulate cell proliferation and apoptosis, including several regulators of apoptosis that were not previously known to be targeted by these transcription factors.

Conclusion: PI 3-kinase signaling in proliferating cells regulates a novel transcriptional program that is highly enriched in genes that regulate apoptosis. At least one-third of these genes are regulated either by FOXO transcription factors, which are activated following PI 3-kinase inhibition, or by RelB, which is activated by PI 3kinase via the non-canonical pathway in proliferating cells.
\end{abstract}




\section{Background}

The PI 3-kinase/Akt signaling pathway plays a critical role in the regulation of growth factor-dependent metabolism, proliferation and survival of mammalian cells $[1,2]$. The downstream targets of Akt that function to regulate cell proliferation and survival include the Bcl-2 family member Bad $[3,4]$ and the pro-apoptotic protein kinase GSK-3 $[5,6]$, both of which are inhibited by Akt phosphorylation. Targets of GSK-3 that have been implicated in cell proliferation and survival include the Bcl-2 family member Mcl-1 [7], cyclin D1 [8], and the translation initiation factor eIF2B [9]. In addition, both Akt and GSK-3 phosphorylate a variety of transcription factors [10-13], and transcriptional regulation plays an important role in the control of cell growth and survival by PI 3-kinase/Akt/ GSK-3 signaling. For example, the FOXO transcription factors are well-characterized substrates of Akt with key roles in cell proliferation and apoptosis. Phosphorylation by Akt leads to the retention of FOXOs in the cytoplasm as a result of binding to $14-3-3$ proteins $[14,15]$. In the absence of PI 3-kinase/Akt signaling, FOXOs translocate to the nucleus and activate transcription of their target genes, including those that encode proteins that induce cell cycle arrest (e.g., p130, p27 and cyclin G2) and apoptosis (e.g., Fas ligand, Trail, and Bim) [16]. Additional transcription factors that are regulated either directly or indirectly by Akt and/or GSK-3 and may be involved in control of PI 3-kinase-dependent cell proliferation and survival include p53 [17], YAP [18], NFאB [19,20], CREB $[21,22]$, c-Myc $[23,24]$, and c-Jun [25].

Although studies of individual transcription factors and their target genes have elucidated several aspects of PI 3kinase signaling, understanding the overall program of transcriptional regulation controlled by the PI 3-kinase/ Akt/GSK-3 pathway requires global expression analysis. We and others have previously used global expression profiling to identify genes whose induction is dependent on PI 3-kinase signaling following growth factor stimulation of quiescent cells [26-29]. Computational analysis to identify transcription factor binding sites that were overrepresented in upstream regions of the PI 3-kinase dependent genes further implicated FOXO, NFкB and CREB as regulators of the induction of these genes in response to growth factor stimulation [26]. Additional studies have identified a subset of these PI 3-kinase-regulated genes that are controlled by GSK-3 and have shown that inhibition of CREB by GSK-3 plays a key role in repressing PI 3-kinase-dependent gene expression in quiescent cells [30].

These studies of transcriptional regulation downstream of PI 3-kinase have examined gene expression in quiescent cells that have been acutely stimulated by growth factor, leading to the robust activation of PI 3-kinase signaling, the rapid induction of immediate-early genes, and the proliferation of cells arrested in $\mathrm{G}_{0}$. A lower level of PI 3kinase signaling is also required for the survival and proliferation of cells that are normally maintained in the presence of growth factors [31]. In the present study, we have examined the gene expression changes that result from inhibition of PI 3-kinase in cells that are actively proliferating in the presence of serum. These experiments identified a novel program of PI 3-kinase-regulated gene expression that is highly enriched in genes that function as regulators of apoptosis and distinct from the program of gene expression induced by growth factor stimulation of quiescent cells. Combined computational and experimental analyses further demonstrated that FOXO and NFKB are major regulators of genes controlled by PI 3-kinase in proliferating cells, and identified new genes with important roles in apoptosis that are targeted by these transcription factors.

\section{Results \\ Identification of Genes Regulated by PI 3-kinase Signaling in Proliferating Cells}

Global expression changes were analyzed in actively proliferating T98G human glioblastoma cells, which are widely used as a model for studies of growth factor regulation of human cells $[26,32,33]$. Similar to previous studies in rat fibroblasts [31], these cells maintained a low level of PI 3-kinase signaling, which was 7 fold higher than in quiescent cells but approximately 5-fold lower than that observed following mitogenic stimulation of quiescent cells with either platelet-derived growth factor (PDGF) or 20\% serum (Fig. 1A). PI 3-kinase was rapidly inhibited in proliferating cells by addition of LY294002 [34], which inhibited phosphorylation of Akt within 15 minutes (Fig. 1B). Inhibition of PI 3-kinase led to the induction of apoptosis, which initiated as early as 3 hours after addition of LY294002 as indicated by DNA fragmentation (Fig. 1C). The fraction of cells undergoing apoptosis gradually increased over several hours (Fig. 1D), typically reaching levels of 25-50\% after 24 hours of PI 3kinase inhibition.

Microarray analyses were performed in three independent experiments to characterize the changes in gene expression resulting from PI 3-kinase inhibition. The number of genes with significantly altered expression $\left(\log _{2}>0.9 ; p<\right.$ 0.01 ) after 2, 4 and 8 hours of treatment with LY294002 are shown in Fig. 2. Inhibition of PI 3-kinase for 2 hours resulted in the up-regulation of 20 genes and down-regulation of 26 genes. After 4 hours of PI 3-kinase inhibition, the number of up-regulated genes slightly increased to a total of 23, whereas the number of down-regulated genes nearly doubled, to a total of 44 . The increase in the number of down-regulated genes was most likely due to the slower rates of mRNA degradation for some genes, 

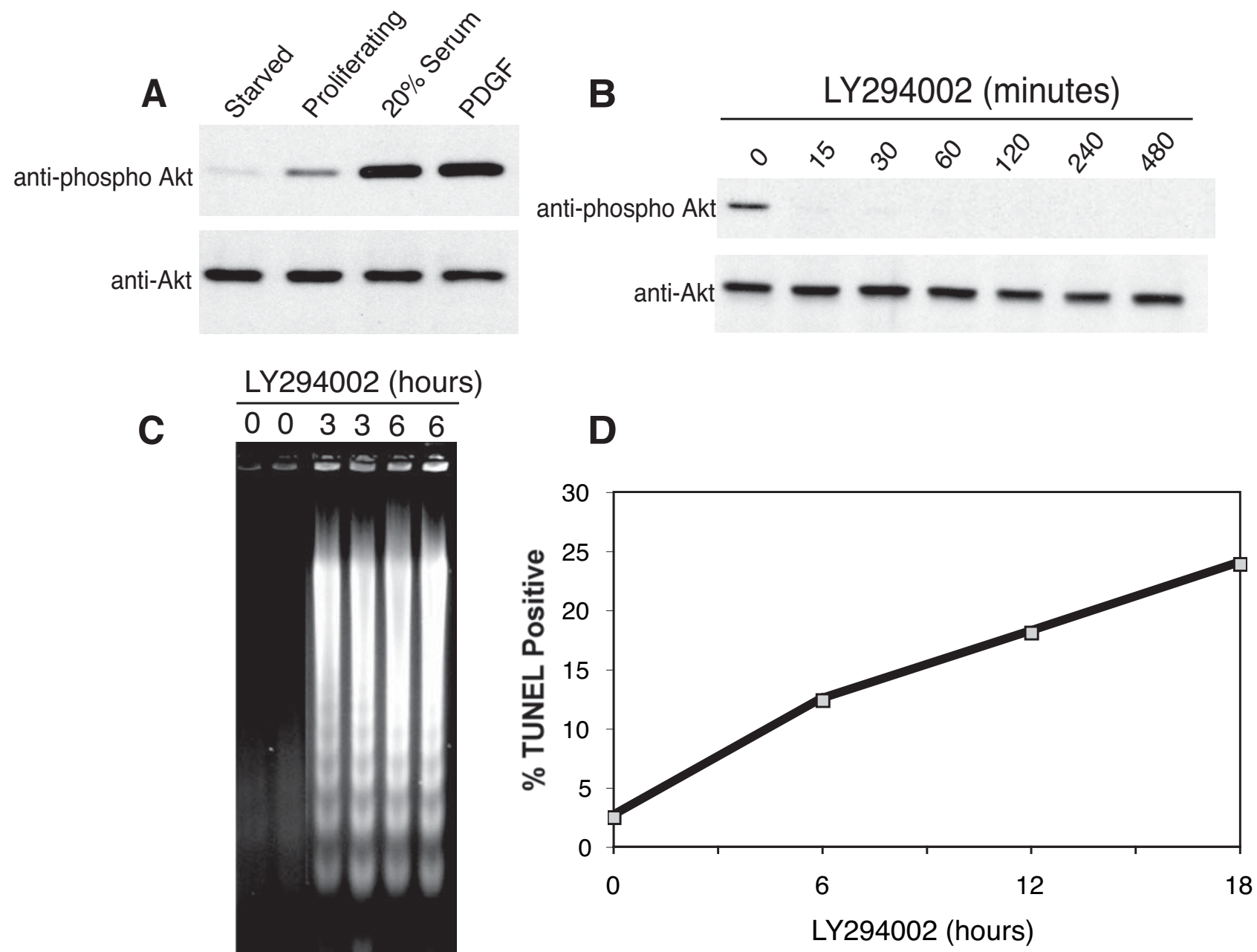

Figure I

Effect of PI 3-kinase inhibition on T98G cells. A, Cell extracts were harvested from starved T98G cells that were rendered quiescent by 72 hours of incubation in serum-free medium, from actively proliferating T98G cells in serum-containing medium, and from quiescent cells that had been stimulated by treatment with $20 \%$ serum or PDGF for 30 minutes. Extracts were subjected to SDS-PAGE and immunoblotted with anti-phospho Akt and pan anti-Akt antibodies. $B$, Actively proliferating T98G cells in serum-containing media were treated with either $50 \mu \mathrm{M}$ LY294002 or 0.1\% DMSO (vehicle control, 0 minute timepoint). Cell extracts were analyzed by immunoblotting. C, Proliferating T98G cells were treated with LY294002 for the indicated times. Cytosolic nucleic acids were isolated and DNA fragmentation was assessed by gel electrophoresis. D, Proliferating T98G cells were harvested at the indicated times after LY294002 treatment, subjected to TUNEL assay, and TUNEL-positive cells quantified by flow cytometry.

thus requiring a longer period for significant decreases in mRNA levels to occur. After 8 hours of PI 3-kinase inhibition, the numbers of both up-regulated and down-regulated genes increased substantially to 118 and 121, respectively, possibly resulting from secondary changes in gene expression.

The genes that were up- or down-regulated following 2 and 4 hours of PI 3-kinase inhibition are summarized in Table 1 (see Additional file 1 for expression changes and for genes with altered expression at 8 hours). Most of the up-regulated genes had increased levels of mRNA after both 2 and 4 hours of inhibition, however 4 genes were significantly up-regulated at 2 hours but returned to baseline at 4 hours, perhaps reflecting transient gene induction. Most down-regulated genes displayed reduced mRNA levels at both 2 and 4 hours, generally decreasing at the longer time of PI 3-kinase inhibition. The microarray data for 7 up-regulated and 11 down-regulated genes were validated by real-time RT-PCR. For all genes tested, 


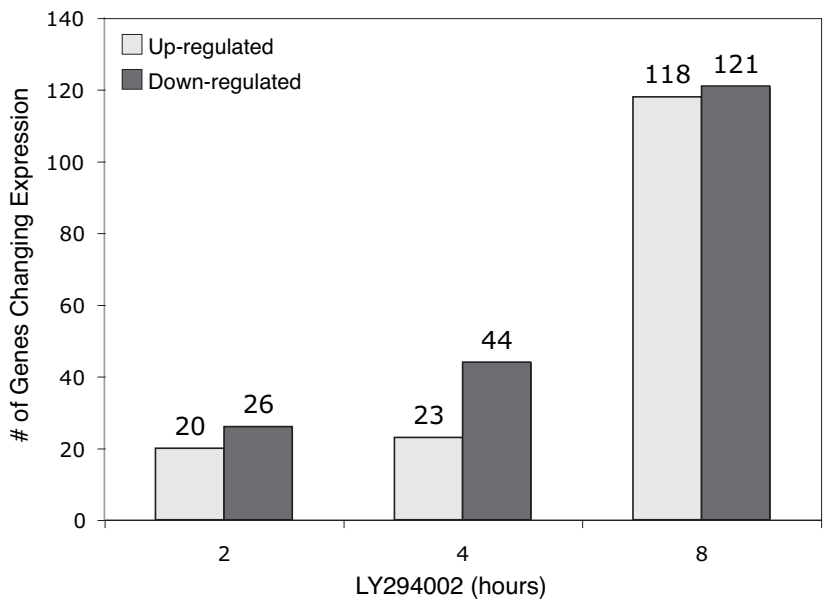

Figure 2

Changes in gene expression resulting from PI 3kinase inhibition. Proliferating T98G cells in serum-containing medium were treated with $50 \mu$ M LY294002 for 2, 4 or 8 hours. Microarray analyses at each timepoint were performed on 3 independent cultures compared to untreated controls. Data are presented as the number of genes that were significantly up-regulated and down-regulated at the specified time of treatment $\left(\log _{2}>0.9, p \leq 0.01\right)$.

the expression changes assessed by real-time RT-PCR after 4 hours of PI 3-kinase inhibition confirmed the microarray results (Additional file 1 ).

Since LY294002 can also inhibit PI 3-kinase-related protein kinases, such as mTOR, we also tested the effect of wortmannin, a more selective PI 3-kinase inhibitor that does not inhibit mTOR at the concentration used (50 nM) [35]. 15 of the 18 genes were similarly up or down-regulated by both wortmannin and LY294002 (Additional file 2 ), indicating that PI 3-kinase was responsible for the changes in expression of these genes. It is possible that the 3 genes whose expression was affected by LY294002 but not wortmannin may be regulated by other targets of LY294002. However $50 \mathrm{nM}$ wortmannin was less effective than LY294002 in inhibiting PI 3-kinase, yielding approximately $90 \%$ rather than complete inhibition of Akt phosphorylation (Additional file 2), so it is also possible that the $10 \%$ of PI 3-kinase signaling remaining after wortmannin treatment was sufficient to maintain normal expression of some genes. In either case, these results support the involvement of PI 3-kinase signaling in the regulation of at least $80-90 \%$ of the genes showing altered expression in response to LY294002.

To determine whether gene expression was similarly regulated in a different cell line, the response of representative genes to inhibition of PI 3-kinase was tested in U937 human promyelocytic leukemia cells (Table 2). The changes in expression of 7 out of 12 genes in response to PI 3-kinase inhibition were similar in both U937 and T98G cells, and 3 other genes were either up- or down-regulated, although to different extents, in both cell lines.

\section{Functions of PI 3-kinase-regulated Genes}

The genes that showed changes in expression after 2 and 4 hours of PI 3-kinase inhibition were largely overlapping and therefore were combined for subsequent analyses. This yielded a gene set in which altered expression was detected around the onset of apoptosis. These genes were compared to a group of 34 immediate-early genes that were induced by PI 3-kinase signaling following PDGF stimulation of quiescent T98G cells [26]. There were only 4 genes in common between the two groups (CTGF, PLAU, CCL2 and F3), indicating that $>90 \%$ of the genes regulated by continual PI 3-kinase signaling were distinct from immediate-early genes induced by PI 3-kinase in response to acute growth factor stimulation.

The genes with altered expression in response to inhibition of PI 3-kinase in T98G cells for 2 and 4 hours included well-known regulators of apoptosis and cell cycle progression. The ability of PI 3-kinase inhibition to induce apoptosis was apparent in the up-regulation of genes that can promote cell death, including DDIT3/ CHOP [36], GADD45B [37], and PHLDA1 [38], and the down-regulation of genes that promote cell survival, including BIRC3/CIAP2 [39] and TNFRSF11B/osteoprotegerin [40]. Additional expression changes included the upregulation of genes that inhibit cell cycle progression, such as CCNG2 [41], BTG1 [42] and GADD45B [43], as well as the down-regulation of CCND1. Genes encoding several growth factors and cytokines that promote cell proliferation and survival (including FGF2, NTF3, EDN1, CCL2 and BDNF) were also down-regulated following inhibition of PI 3-kinase.

The Gene Ontology (GO) database was used to further characterize the functions of the genes regulated by PI 3kinase. The frequencies of the GO terms assigned to the PI 3-kinase-regulated set of genes were compared to the frequencies of all annotated genes on the microarray. Biological Process GO terms that were significantly enriched $(p<$ 0.001 ) and identified in at least $15 \%$ of the GO-annotated genes that were either up- or down-regulated following 2 and 4 hours of inhibition of PI 3-kinase are indicated in Table 3. The larger set of genes with altered expression after 8 hours of PI 3-kinase inhibition did not display enrichment of GO terms at this level of statistical significance. The up-regulated genes were enriched in GO categories related to development, differentiation, and response to stress, as well as in GO terms related to transcriptional regulation. These GO categories, particularly "response to stress", include such genes as DDIT3/CHOP 
Table I: Gene expression changes after 2 and 4 hours of PI 3-kinase inhibition

\begin{tabular}{|c|c|c|c|}
\hline \multicolumn{2}{|c|}{ Up-Regulated Genes } & \multicolumn{2}{|c|}{ Down-Regulated Genes } \\
\hline Gene Symbol & Gene Name & Gene Symbol & Gene Name \\
\hline APOLDI & Apolipoprotein L domain containing I & AMDI & S-adenosylmethionine decarboxylase I \\
\hline Atrogin-I & F-box protein 32/Atrogin-I & AMIGO2 & Adhesion molecule with Ig-like domain 2 \\
\hline BCL6 & B-cell CLL/lymphoma 6 & ATPI $3 A 3$ & ATPase type $13 \mathrm{~A} 3$ \\
\hline BTGI & B-cell translocation gene I & BAG2 & BCL2-associated athanogene 2 \\
\hline Clorfl 83 & Chromosome I open reading frame 183 & $B D N F$ & Brain-derived neurotrophic factor \\
\hline $\mathrm{Clorf63}$ & Chromosome I open reading frame 63 & BIRC3/CIAP2 & Baculoviral IAP repeat-containing 3 \\
\hline CCNG2 & Cyclin G2 & $C C L 2$ & Chemokine (C-C motif) ligand 2 \\
\hline CLKI & CDC-like kinase I & CCNDI & Cyclin DI \\
\hline CTGF & Connective tissue growth factor & CYPIBI & Cytochrome P450 subfamily I polypeptide I \\
\hline DDIT3/CHOP & DNA-damage-inducible transcript 3 & DCK & Deoxycytidine kinase \\
\hline EIFI/SUII & Eukaryotic translation initiation factor I & DIO2 & Deiodinase, iodothyronine, type II \\
\hline GADD45B & Growth arrest and DNA-damage-inducible $\beta$ & DKFZP686E2158 & Hypothetical protein LOC643I55 \\
\hline$|D|$ & Inhibitor of DNA binding I & DKKI & Dickkopf homolog I (Xenopus laevis) \\
\hline ID2B & Striated muscle contraction regulatory prot. & DSCRI & Down syndrome critical region gene I \\
\hline IRF7 & Interferon regulatory factor 7 & EDNI & Endothelin I \\
\hline KIFIB & Kinesin family member IB & F3 & Coagulation factor III \\
\hline KLF6 & Kruppel-like factor 6 & FGF2 & Fibroblast growth factor 2 \\
\hline KLHL24 & Kelch-like 24 & FST & Follistatin \\
\hline LOC85028 & PNAS- 123 & GOS2 & Putative lymphocyte G0/GI switch gene \\
\hline MIR & Myosin regulatory light chain interacting prot. & GABPB2 & GA binding protein transcription factor, $\beta 2$ \\
\hline MTIE & Metallothionein IE & GBPI & Guanylate binding protein I \\
\hline PCMTDI & Protein-L-isoaspartate O-methyltransferase & GBP3 & Guanylate binding protein 3 \\
\hline PHLDAI & Pleckstrin homology-like domain family A & GLIPRI & Glioma pathogenesis-related protein \\
\hline PNPLA8 & Patatin-like phospholipase domain 8 & GPRI9 & G protein-coupled receptor 19 \\
\hline RNU2 & RNA, U2 small nuclear & GRIKI & Glutamate receptor, ionotropic, kainate I \\
\hline SAT & Spermine NI-acetyltransferase & GRO3 & GRO3 oncogene \\
\hline STK3I & Serine/threonine kinase 31 & IGFBP5 & Insulin-like growth factor binding protein 5 \\
\hline TAF9 & TAF9 RNA polymerase II & IL7R & Interleukin 7 receptor \\
\hline TIEG & TGF $\beta$ inducible early growth response & ISG2OLI & Interferon stimulated exonuclease \\
\hline TXNIP & Thioredoxin interacting protein & LOC57090 & HRPAP20 short form \\
\hline \multirow[t]{23}{*}{ ZBTBI } & Zinc finger and BTB domain containing I & LTVI & LTVI homolog (S. cerevisiae) \\
\hline & cDNA DKFZp564C2063 & MAT2A & Methionine adenosyltransferase II, alpha \\
\hline & & MMP3 & Matrix metalloproteinase 3 \\
\hline & & NAV3 & Neuron navigator 3 \\
\hline & & NCOA7 & Nuclear receptor coactivator 7 \\
\hline & & NOLAI & Nucleolar protein family A, member I \\
\hline & & NTF3 & Neurotrophin 3 \\
\hline & & NXTI & NUTF-like export factor I \\
\hline & & PAKIIPI & PAKI interacting protein I \\
\hline & & PLAU & Plasminogen activator, urokinase \\
\hline & & PPIF & Peptidylprolyl isomerase F (cyclophilin F) \\
\hline & & PTRH2 & Peptidyl-tRNA hydrolase 2 \\
\hline & & PTX3 & Pentaxin-related gene \\
\hline & & RGS20 & Regulator of G-protein signalling 20 \\
\hline & & SC4MOL & Sterol-C4-methyl oxidase-like \\
\hline & & SFRS3 & Splicing factor, arginine/serine-rich 3 \\
\hline & & SGNEI & Secretory granule, neuroendocrine protein I \\
\hline & & SNK & Serum-inducible kinase \\
\hline & & STC2 & Stanniocalcin 2 \\
\hline & & TNFRSFI IB & Tumor necrosis factor receptor IIb (OPG) \\
\hline & & TRIM I6 & Tripartite motif-containing 16 \\
\hline & & $T S L P$ & Thymic stromal lymphopoietin \\
\hline & & & cDNA FLJII I I 2 fis, clone HEMBA 1006364 \\
\hline
\end{tabular}


Table 2: Comparison of the effect of PI 3-kinase inhibition on gene expression in $U 937$ and T98G cells.

\begin{tabular}{lcc}
\hline & \multicolumn{2}{c}{ Fold Change } \\
& U937 cells & T98G cells \\
\hline Up-regulated genes & & \\
\hline BCL6 & & \\
BTGI & 1.3 & 2.8 \\
CCNG2 & 3.4 & 4.1 \\
DDIT3/CHOP & $\mathbf{6 . 6}$ & 3.0 \\
IRF7 & 1.3 & 2.2 \\
KLF6/COPEB & $\mathbf{7 . 6}$ & $\mathbf{4 . 2}$ \\
& $\mathbf{5 . 7}$ & $\mathbf{1 . 5}$
\end{tabular}

\section{Down-regulated genes}

\begin{tabular}{lll}
\hline BAG2 & 3.3 & 4.3 \\
BIRC3/CIAP2 & 1.7 & 8.9 \\
CCL2 & 51 & 11 \\
F3 & 1.8 & 4.8 \\
IL7R & 2.5 & 2.6 \\
PLAU & 3.4 & 2.1
\end{tabular}

Proliferating U937 and T98G cells were treated with LY294002 for 4 hours and gene expression was quantitated by RT-PCR. Data are expressed as average fold changes from two independent experiments. Genes in bold were up- or down-regulated in both cell lines.

[36] and GADD45B [37], and are consistent with the increased expression of genes involved in apoptosis and cell cycle arrest following inhibition of PI 3-kinase. The down-regulated genes were enriched in GO terms related to cell signaling and programmed cell death, consistent with the role of PI 3-kinase signaling in preventing apoptosis. These included genes encoding growth factors and cytokines as well as central negative regulators of apoptosis, such as BIRC3/cIAP2 [39] and the TRAIL decoy receptor, TNFRSF11B/osteoprotogerin [40].

\section{Prediction of Transcription Factor Binding Sites in PI 3- Kinase Regulated Genes}

Co-expressed genes are often regulated by common transcription factors, therefore we analyzed the upstream regions of different sets of PI 3-kinase-regulated genes to identify over-represented transcription factor binding sites [26,30,44]. Predictions of functional transcription factor binding sites can be improved by incorporating phylogenetic data to identify sites that are evolutionarily conserved [45], so we focused on sites that were conserved in orthologous genomic regions of human and mouse. We independently analyzed the sets of genes that were either up- or down-regulated following PI 3-kinase inhibition, and also separately analyzed the genes that showed altered expression after 2 and 4 hours of PI 3-kinase inhibition and those that showed altered expression after 8 hours of PI 3-kinase inhibition. Regions $3 \mathrm{~kb}$ upstream of the transcription start sites in the human and correspond- ing mouse sequences were analyzed with the Match program using the minSUM threshold, and both the 546 vertebrate matrices in TRANSFAC Professional v8.4 and the 588 matrices in TRANSFAC Professional v11.1. Overrepresentation of transcription factor binding sites was assessed by comparing the frequency of predicted sites in each set of genes to the frequencies in a background set of genes that were expressed in proliferating T98G cells but not affected by PI 3-kinase inhibition (see Additional file 3 for complete results).

No significantly over-represented binding sites were identified in the sets of genes that were either up- or down-regulated following 8 hours of PI 3-kinase inhibition, perhaps because these large sets of genes are regulated by a diverse group of transcription factors or by other mechanisms, such as mRNA degradation. However, over-represented binding site matrices were identified in the sets of genes that were either up- or down-regulated after 2 and 4 hours of PI 3-kinase inhibition.

When the results from TRANSFAC v8.4 and v11.1 were combined, there were 9 matrices that were significantly over-represented in the up-regulated genes (Table 4). These included matrices for the forkhead family of transcription factors, as well as for Myc/Max and NF-Y. The most significant matrices represented forkhead family proteins, which together predicted binding sites in $82 \%$ of the up-regulated genes. The down-regulated genes were enriched in 4 matrices, 2 for NFKB and 2 for HMGI(Y). When the results from TRANSFAC v8.4 and v11.1 were combined, $27 \%$ of the genes had at least one NFKB binding site. The clear enrichment of forkhead and NFkB binding sites in the up- and down-regulated genes, respectively, as well as the fact that members of both of these families of transcription factors are known targets of $\mathrm{Akt}$, led us to further investigate the roles of forkhead and $\mathrm{NF \kappa B}$ in the transcriptional response of genes regulated by inhibition of PI 3-kinase.

\section{Analysis of FOXO Regulation and Target Genes}

The FOXO transcription factors are inhibited by Akt phosphorylation of Thr-24, Ser-256, and Ser-319 on FOXO1 and the equivalent sites on FOXO3 and FOXO4 [16]. Phosphorylation of these residues results in the binding of 14-3-3 proteins, which inhibits nuclear shuttling and transcriptional activity of the FOXOs. We investigated the expression of FOXO transcription factors in T98G cells and their response to PI 3-kinase inhibition by subcellular fractionation and immunoblotting (Fig. 3). FOXO1 and FOXO3a were expressed in T98G cells and were principally localized to the cytoplasm in cells maintained in serum (FOXO4 was not detectable, data not shown). Addition of LY294002 resulted in the nuclear accumulation of both FOXO1 and FOXO3a within 30 minutes, 
Table 3: Summary of Gene Ontology (GO) term analysis.

\begin{tabular}{|c|c|c|c|c|}
\hline GO ID & GO name & \# Genes & $\%$ Genes & $p$-value \\
\hline \multicolumn{5}{|c|}{ Up-regulated Genes } \\
\hline GO:0032502 & Developmental process & 15 & 60 & 0.00002 \\
\hline GO:0048869 & Cellular developmental process & 12 & 48 & 0.00003 \\
\hline GO:0030154 & Cell differentiation & 12 & 48 & 0.00003 \\
\hline GO:0000I22 & Negative regulation of transcription from RNA polymerase II promoter & 4 & 16 & 0.00007 \\
\hline GO:0045892 & Negative regulation of transcription, DNA-dependent & 4 & 16 & 0.00033 \\
\hline GO:0006366 & Transcription from RNA polymerase II promoter & 6 & 24 & 0.00064 \\
\hline GO:0006950 & Response to stress & 7 & 28 & 0.00068 \\
\hline GO:0050794 & Regulation of cellular process & 14 & 56 & 0.00087 \\
\hline \multicolumn{5}{|c|}{ Down-regulated Genes } \\
\hline GO:0048519 & Negative regulation of biological process & 13 & 27 & 0.000040 \\
\hline GO:0007267 & Cell-cell signaling & 10 & 21 & 0.000040 \\
\hline GO:0007I54 & Cell communication & 23 & 48 & 0.000077 \\
\hline GO:00I250I & Programmed cell death & 10 & 21 & 0.000083 \\
\hline GO:0048523 & Negative regulation of cellular process & 12 & 25 & 0.000085 \\
\hline GO:0007I65 & Signal transduction & 21 & 44 & 0.000130 \\
\hline GO:0008219 & Cell death & 10 & 21 & 0.000134 \\
\hline GO:0016265 & Death & 10 & 21 & 0.000134 \\
\hline GO:0009887 & Organ morphogenesis & 7 & 15 & 0.000169 \\
\hline GO:0009605 & Response to external stimulus & 8 & 17 & 0.000432 \\
\hline GO:0042221 & Response to chemical stimulus & 7 & 15 & 0.000490 \\
\hline GO:0007166 & Cell surface receptor linked signal transduction & 12 & 25 & 0.000632 \\
\hline GO:0009653 & Anatomical structure morphogenesis & 10 & 21 & 0.000840 \\
\hline
\end{tabular}

All GO terms in the Biological Process category that were significantly enriched [ $p \leq 0.00$ I, Fisher's exact test [76]] amongst the genes changing expression after 2 and 4 hours of LY294002 treatment and were represented in at least I5\% of the genes containing GO definitions are listed. The GO ID and name are shown along with the number and percentage of genes that are assigned this term.

consistent with their involvement in the transcriptional response of T98G cells to PI 3-kinase inhibition.

Chromatin immunoprecipitation (ChIP) assays were therefore used to test the predicted FOXO binding sites in genes that were induced upon PI 3-kinase inhibition. Exponentially growing T98G cells were transiently transfected with a plasmid expressing a Flag-tagged FOXO3aAAA mutant [46] and immunoprecipitations of sheared chromatin were performed with Flag-antibody. The FlagFOXO3a-AAA is a constitutively active mutant in which the three Akt phosphorylation sites have been mutated to alanines, resulting in its constitutive nuclear localization. ChIP assays were performed on three independent transfected cell cultures to test predicted FOXO binding sites upstream of 21 up-regulated genes (two open reading frames with predicted FOXO binding sites were not tested, C1orf63 and C1orf183, due to their hypothetical protein designation). Flag-FOXO3a-AAA specifically bound to upstream regions of 10 of these 21 genes, compared to cells transfected with empty vector or to the negative control gene $\beta$-globin (Fig. 4). These verified FOXO binding sites are indicated in Table 5 (see Additional file 4 for all sites tested). These 10 genes included 4 with previously established FOXO upstream binding sites [CCNG2 [46,47], BTG1 [48], BCL-6 [49,50] and ATROGIN-1 [51] as well as 6 genes not previously identified as having binding sites for FOXO (ZBTB1, KIF1B, KLFG, KLHL24, DDIT3/ CHOP and TXNIP).

\section{Analysis of NFKB Regulation and Target Genes}

In contrast to the forkhead family, Akt indirectly activates NFkB transcription factors, at least in part by phosphorylation of IкB kinase (IKK) $[19,20]$. There are 5 different NFKB family members (p65, c-Rel, RelB, p50 and p52), which all bind to a similar consensus sequence and can be activated by several pathways that converge on IKK [52]. Because the majority of NFKB binding sites are occupied after stimulation with cytokines [53], we initially performed ChIP assays following treatment of T98G cells with tumor necrosis factor $\alpha(\mathrm{TNF} \alpha)$ to determine if $\mathrm{p} 65$ was able to bind to the sites predicted in the genes that were down-regulated upon PI 3-kinase inhibition. In addition to the sites predicted by the matrices indicated in Table 4, we tested conserved sites predicted by 7 additional NFKB matrices to ensure that most functional binding sites were identified. When all matrices were considered, 25 NFKB sites were predicted in a total of 20 
Table 4: Over-represented transcription factor binding sites in genes that were differentially expressed after PI 3-kinase inhibition.

\begin{tabular}{|c|c|c|c|c|}
\hline Transcription factor & TRANSFAC Matrix & TRANSFAC version & $\%$ Genes with site & $p$-value \\
\hline \multicolumn{5}{|l|}{ Up-regulated genes } \\
\hline \multirow[t]{10}{*}{ Forkhead family members } & V\$FOXJ2_0I & 8.4 & 29 & 0.004 \\
\hline & V\$HFH3_OI & 8.4 & 29 & 0.004 \\
\hline & V\$FOXOI_0I & 8.4 & 46 & 0.007 \\
\hline & V\$FOXO4_0I & 8.4 & 43 & 0.018 \\
\hline & V\$HFHI_OI & 11.1 & 57 & 0.001 \\
\hline & V\$FOXŌ_0I & II.I & 71 & 0.004 \\
\hline & V\$FOXO3_0I & 11.1 & 75 & 0.004 \\
\hline & V\$FOXOI_02 & II.I & 71 & 0.006 \\
\hline & V\$HFH8_0I & II.I & 57 & 0.009 \\
\hline & V\$FOXJ2_0I & 11.1 & 43 & 0.016 \\
\hline \multirow[t]{2}{*}{ Myc/Max } & V\$MYCMAX_B & 8.4 & 39 & 0.013 \\
\hline & V\$MYCMAX_B & II.I & 39 & 0.009 \\
\hline NF-Y & V\$NFY_Q6 & II.I & 46 & 0.010 \\
\hline \multicolumn{5}{|l|}{ Down-regulated genes } \\
\hline \multirow[t]{2}{*}{$N F_{\kappa} B$} & V\$NFKAPPAB65_0I & 8.4 & 12 & 0.017 \\
\hline & V\$NFKAPPAB_0I & II.I & 27 & 0.014 \\
\hline \multirow[t]{2}{*}{ HMGI(Y) } & V\$HMGIY_Q6 & II.I & 80 & 0.014 \\
\hline & V\$HMGIY_Q3 & II.I & 73 & 0.014 \\
\hline
\end{tabular}

The $3 \mathrm{~kb}$ regions upstream of the transcription start sites in the human and mouse orthologous sequences were analyzed with the Match algorithm using the MinSUM threshold and both TRANSFAC v8.4 and vII.I in order to identify over-represented matrices. $P$-values were calculated using the permutation test and adjusted for multiple testing by FDR correction. Significant matrices were those with $p<0.02$ that predicted less than I match in $\mathrm{I} \mathrm{kb}$ of sequence in the background set.

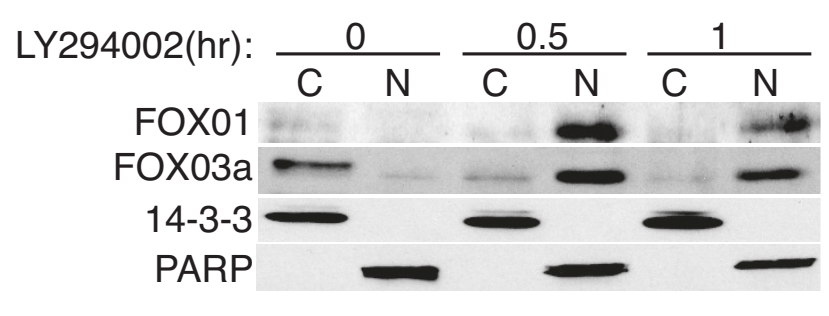

Figure 3

Nuclear translocation of FOXOI and FOX03a upon LY294002 treatment. T98G cells were fractionated into nuclear ( $\mathrm{N} ; \sim 2 \mu \mathrm{g}$ protein) and cytosolic (C; $\sim 25 \mu \mathrm{g}$ protein) fractions following treatment with LY294002 for the indicated times. Samples were then immunoblotted for the presence of FOXOI and FOX03a. To confirm isolation of nuclear and cytosolic fractions, blots were reprobed with antibodies against PARP (nuclear marker) and I4-3-3 (cytosolic marker). The LY294002 vehicle (DMSO) showed no translocation (data not shown). Shown are representative blots from two independent experiments. of the down-regulated genes (See Additional file 4 for all sites).

TNF $\alpha$ activates NFkB through the canonical pathway, in which IKK $\beta$ phosphorylates I $\mathrm{B}$, which predominantly serves to activate the p50-p65 NFкB heterodimer. Cells treated with TNF $\alpha$ for $0.25,0.5$ or 1 hour were therefore analyzed by ChIP using anti-p65 antibody. Of the 25 predicted sites, 22 sites in 18 genes exhibited increased p65 binding in response to $\mathrm{TNF} \alpha$, which was significantly greater than binding to the $\beta$-globin negative control (Fig. 5 ). The binding sites (Table 6 ) included several that were previously known [BIRC3/cIAP2 [54], CCL2 [55], CCND1 [56], EDN1 site I [57], F3 site II [58], GABPB2 [53], IL7R site II [59], MAT2A site II [60], PLAU [61] and PTX3 [62], in addition to novel binding sites in genes known to be targeted by NFKB [BDNF [63], EDN1 site II, F3 site I, IL7R site $\mathrm{I}$ and $M A T 2 A$ site $\mathrm{I}]$, as well as binding sites in novel NFkB-regulated genes (AMIGO2, FST, G0S2, IGFBP5, RGS20, STC2 and TNFRSF11B/osteoprotegerin). Note that some of these verified NFKB binding sites were predicted with either Transfac v8.4 or v11.1, but not both. 


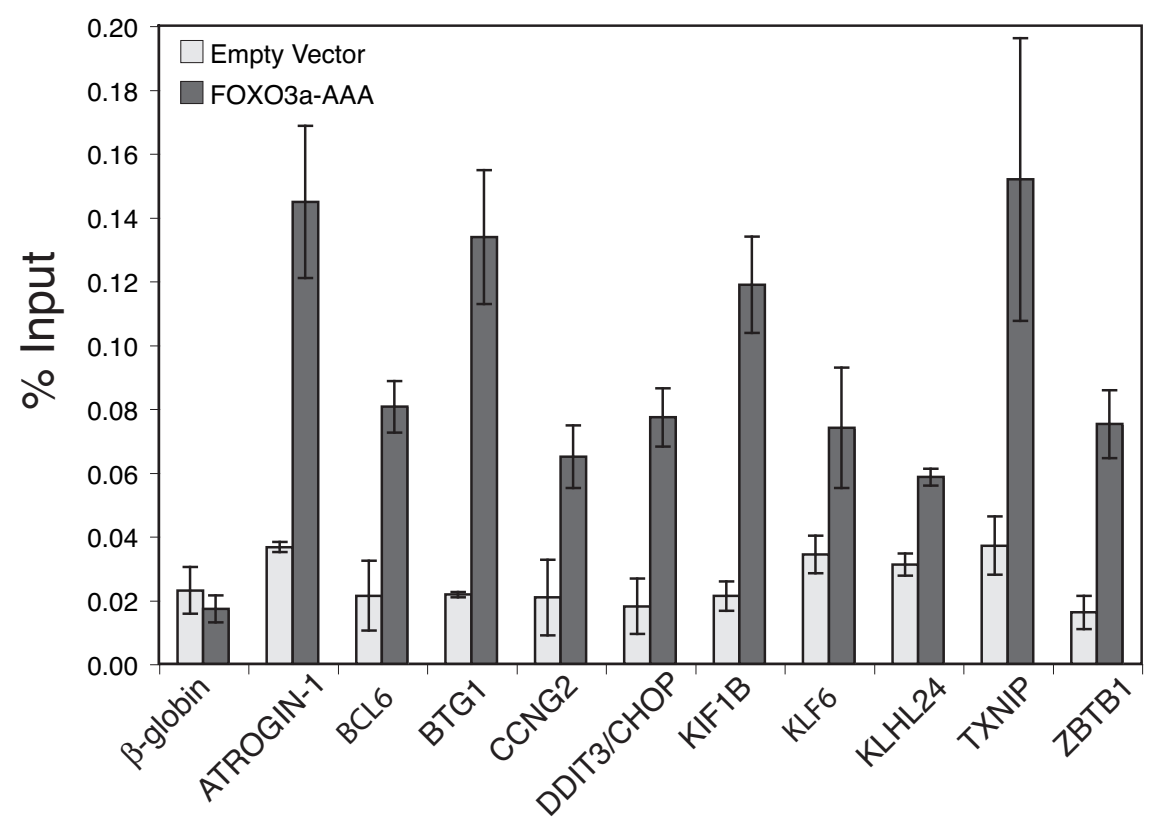

\section{Figure 4}

Analysis of FOXO binding sites by chromatin immunoprecipitation. T98G cells were transfected with an empty PCDNA3 control or Flag-FOXO3a-AAA expression vector for 24 hours. Chromatin fragments were immunoprecipitated with anti-Flag antibody and quantified by real-time PCR (see Additional file 4 for primers). Data are presented as percentage of input and are the means of 3 independent transfections \pm S.E $\beta$-globin is a negative control. Immunoblots indicated that the expression of FOXO3a-AAA in transfected cells was 3-5 fold greater than the endogenous protein.

p65 did not show increased binding to any of the predicted sites in the absence of TNF $\alpha$ stimulation as compared to the $\beta$-globin control (Fig. 5), which was expected due to its sequestration in the cytoplasm by $\mathrm{I} \kappa \mathrm{B}$ proteins. However, other members of the NFKB family can be found in the nucleus of proliferating cells in the absence of cytokine stimulation. p50 and p52 do not bind $\mathrm{I} \kappa \mathrm{B}$ proteins but rather enter the nucleus following their generation from cleavage of larger precursors (p105 and p100, respectively). Both p50 and p52 lack activation domains, but p52-RelB heterodimers are also able to translocate into the nucleus and activate transcription of their target genes. In the non-canonical pathway of NFKB activation, IKK $\alpha$ phosphorylation of p100 results in its conversion to $\mathrm{p} 52$, which forms a transcriptionally active complex with RelB [52]. Since the non-canonical pathway is stimulated by Akt and can be active in the absence of cytokine stimulation [64], it might be responsible for $\mathrm{NFKB}$ activity in cells proliferating in serum growth factors.

We therefore performed ChIP assays to measure the basal levels of binding of several NFKB family members to the predicted NFKB binding sites in proliferating cells in the presence of serum. As was observed for p65 (see Fig. 5), cRel, which is also activated by the canonical pathway, did not bind to upstream regions of any of the genes (data not shown). In contrast, p50, p52 and RelB bound to the predicted sites in several genes, most strikingly PTX3 and BIRC3/cIAP2 (Fig. 6). RelB ChIP assays were performed on three independent cultures so that a statistical comparison could be made between the genes with predicted sites and the $\beta$-globin negative control. This analysis indicated significant binding $(p<0.05)$ of RelB to NFKB sites upstream of 7 genes in T98G cells maintained in serum, including known NFKB sites upstream of BIRC3/cIAP2, CCL2, CCND1, GABPB2, MAT2A (site II), PLAU and PTX3, and a novel site in MAT2A (site I).

Because RelB has a transactivation domain and the predicted sites occurred upstream of genes that were downregulated in response to PI 3-kinase inhibition, we next sought to determine if RelB binding decreased in cells that were treated with LY294002 to inhibit PI 3-kinase. ChIP assays were performed in triplicate to measure RelB binding to the confirmed binding sites in the 7 genes mentioned previously (Fig. 7). Inhibition of PI 3-kinase led to a significant decrease in RelB binding $(p<0.05)$ to the sites in BIRC3, CCL2 and PTX3, consistent with PI 3kinase regulation of these genes through the non-canonical NFкB pathway. 
Table 5: FOXO binding sites confirmed by chromatin immunoprecipitation.

\begin{tabular}{|c|c|c|c|c|}
\hline Gene & Binding site position & TRANSFAC 8.4 & TRANSFAC II.I & Primer Position \\
\hline \multirow[t]{3}{*}{ ATROGIN-I } & -31 & & V\$HFH8_0I & -160 \\
\hline & -118 & V\$FOXOI_0I & V\$HFHI_OI & \\
\hline & -136 & V\$FOXOI_0I & V\$FOXOI_0I & \\
\hline \multirow[t]{4}{*}{$B C L 6$} & -837 & & V\$HFHI_OI & -1126 \\
\hline & -881 & & V\$FOXOI_02 & \\
\hline & -991 & V\$FOXJ2_0I & V\$HFHI_OI & \\
\hline & -1419 & & V\$HFHI_OI & \\
\hline \multirow[t]{3}{*}{ BTGI } & -213 & V\$FOXJ2_0I & V\$FOXOI_0I & -254 \\
\hline & -220 & & V\$HFHI_OI & \\
\hline & -496 & V\$FOXOI_0I & V\$HFHI_OI & \\
\hline \multirow[t]{5}{*}{ CCNG2 } & -158 & V\$FOXOI_0I & V\$HFHI_OI & -243 \\
\hline & -165 & & V\$FOXOI_0I & \\
\hline & -469 & & V\$FOXOI_0I & \\
\hline & -473 & V\$FOXOI_0I & V\$FOXO3_0I & \\
\hline & -483 & & V\$FOXOI_0I & \\
\hline \multirow[t]{4}{*}{ DDIT3/CHOP } & -1544 & & V\$FOXOI_0I & -1973 \\
\hline & -1606 & & V\$HFHI_OI & \\
\hline & -1830 & & V\$FOXOI_02 & \\
\hline & -2069 & & V\$FOXOI_0I & \\
\hline$K I F I B$ & -673 & & V\$FOXOI_0I & -673 \\
\hline \multirow[t]{3}{*}{ KLF6 } & -955 & V\$FOXOI_0I & V\$HFHI_0I & -947 \\
\hline & -929 & V\$FOXO3_0I & & \\
\hline & -887 & V\$FOXJ2_OI & V\$HFHI_OI & \\
\hline \multirow[t]{2}{*}{ KLHL24 } & -14 & & V\$FOXO3_0I & -211 \\
\hline & -34 & & V\$FOXOI_0I & \\
\hline$T X N I P$ & -216 & V\$FOXOI_0I & V\$HFHI_OI & -250 \\
\hline ZBTBI & -252 & & V\$FOXOI_02 & -263 \\
\hline
\end{tabular}

The predicted FOXO binding sites that were confirmed by ChIP are indicated by the most 5 ' nucleotide. When multiple matrices predicted overlapping sites, the position indicates the most 5 ' nucleotide of the consensus sequence (see Additional file 4 for all sequences). The TRANSFAC matrices shown are those that predicted the indicated sites with the lowest $p$-values. ChIP assays were considered to confirm binding sites located within 500 bp of the primer position. Primer positions are indicated by the most 5' nucleotide of the forward primer; all amplicons were 50-60 bp.

\section{Discussion}

The PI 3-kinase/Akt/GSK-3 signaling pathway plays a central role in regulation of growth factor-dependent proliferation and survival of mammalian cells, at least in part by transcriptional regulation. A number of transcription factors and target genes that are regulated by PI 3-kinase signaling have been studied on an individual basis. In addition, both we [26,30,44] and others [27-29] have used global expression profiling to investigate the overall program of gene regulation controlled by PI 3-kinase/Akt/ GSK-3 signaling. These studies have focused on the response of quiescent cells to growth factor stimulation, which induces robust activation of PI 3-kinase, induction of immediate-early genes, and re-entry into the cell cycle.
However, a lower level of continuous PI 3-kinase signaling is also required to maintain proliferation and survival of cells in the presence of serum growth factors. In the present study, we have therefore undertaken a global analysis of the transcriptional program that maintains cell survival and proliferation downstream of PI 3-kinase signaling in proliferating cells.

Inhibition of PI 3-kinase in actively proliferating T98G cells for 2 and 4 hours resulted in up-regulation of 32 genes and down-regulation of 53 genes. These gene expression changes occurred around the time at which apoptosis was first detected. Consistent with their involvement in apoptosis, the genes with altered expression fol- 


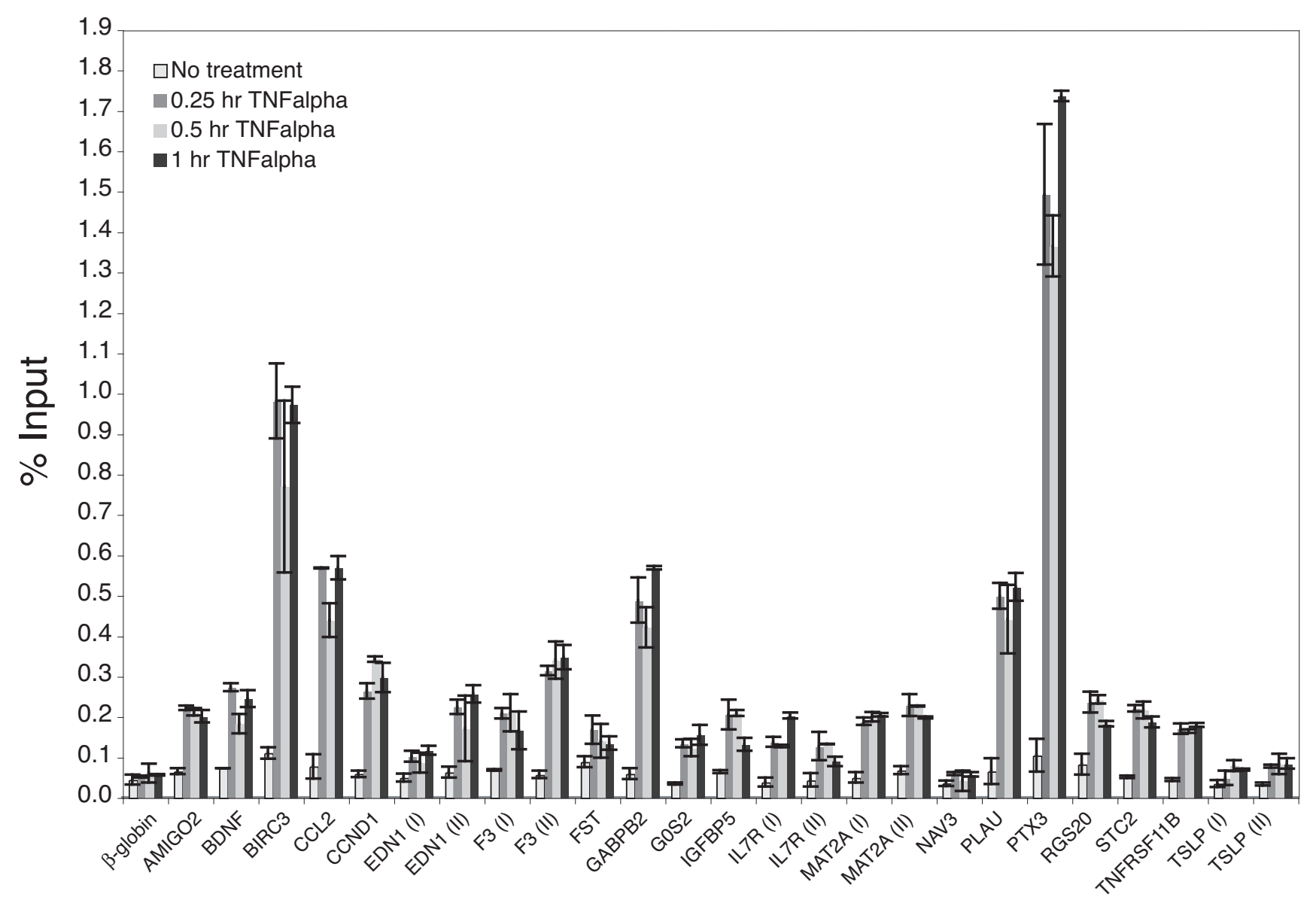

Figure 5

Analysis of NF $\kappa$ B binding sites in TNF $\alpha$-stimulated cells by chromatin immunoprecipitation. T98G cells proliferating in serum-containing media were either left untreated or stimulated with TNF $\alpha$ for I5, 30 or 60 minutes. Chromatin fragments were immunoprecipitated with anti-p65 antibody and quantified by real-time PCR. Data are presented as the percentage of input and are the means of 2 independent experiments \pm S.E. $\beta$-globin was used as the negative control.

lowing 2 and 4 hours of PI 3-kinase inhibition included growth factors and cytokines, as well as several wellknown regulators of apoptosis (such as DDIT3/CHOP, GADD45B, PHLDA1, BIRC3/cIAP2 and TNFRSF11B/osteoprotegerin) and cell cycle progression (such as CCNG2 and CCND1). Functional classifications using the Gene Ontology database further indicated that these gene sets were enriched in terms related to cell stress and programmed cell death, as well as to cell signaling and transcriptional regulation. The numbers of up- and down-regulated genes both increased substantially, to a total of nearly 250 genes, after 8 hours of PI 3-kinase inhibition, probably reflecting a secondary transcriptional response. This larger set of genes was no longer significantly enriched in functional GO terms.

We compared the sets of genes with altered expression following 2 and 4 hours of PI 3-kinase inhibition to those identified by previous studies of the genes induced following 0.5-4 hours of growth factor simulation of quiescent T98G cells $[26,44]$. Only $~ 10 \%$ of the genes affected by inhibition of PI 3-kinase overlapped with either the total sets of immediate-early or delayed primary response genes, or with the subset of PI 3-kinase dependent immediate-early genes defined in these previous studies. Similar to the genes that were up-regulated following inhibition of PI 3-kinase, immediate-early genes induced in response to growth factor stimulation were enriched in GO terms related to transcriptional regulation [44]. However, the transcription factors induced as immediate-early genes by growth factor stimulation are different from those that are up-regulated in response to PI 3-kinase inhibition. The genes regulated by continuous PI 3-kinase signaling in proliferating cells were thus clearly distinct from the primary response genes induced by growth factor stimulation of quiescent cells. 
Table 6: NFKB binding sites confirmed by chromatin immunoprecipitation.

\begin{tabular}{|c|c|c|c|c|}
\hline Gene & Binding site position & TRANSFAC 8.4 & TRANSFAC II.I & Primer Position \\
\hline AMIGO2 & -721 & & V\$NFKAPPAB_0I & -795 \\
\hline$B D N F$ & -223 & V\$CREL_0I & V\$NFKAPPAB_0I & -586 \\
\hline \multirow[t]{3}{*}{ BIRC3/CIAP2 } & -92 & V\$CREL_0I & & -75 \\
\hline & -115 & & V\$NFKAPPAB65_0I & \\
\hline & -178 & V\$NFKAPPAB65_0I & V\$NFKAPPAB_0I & \\
\hline \multirow[t]{3}{*}{ CCL2 } & -2602 & V\$NFKAPPAB65_0I & V\$NFKAPPAB_0I & -2763 \\
\hline & -2631 & V\$NFKAPPAB_0I & V\$NFKAPPAB_OI & \\
\hline & -2804 & V\$CREL_0I & V\$NFKAPPAB_0I & \\
\hline CCNDI & -698 & V\$CREL_0I & & -701 \\
\hline \multirow[t]{3}{*}{ EDNI } & -225 (II) & V\$CREL_0I & & -241 \\
\hline & -293 (II) & V\$CREL_0I & & \\
\hline & $-2263(I)$ & V\$CREL_0I & & -2252 \\
\hline \multirow{3}{*}{ F3 } & -188 (II) & V\$NFKAPPAB65_0I & V\$CREL_0I & -351 \\
\hline & -482 (II) & V\$CREL_0I & V\$NFKAPPAB_0I & \\
\hline & $-2373(\mathrm{I})$ & V\$NFKAPPAB65_0I & V\$NFKAPPAB_0I & -2358 \\
\hline FST & -1335 & V\$CREL_0I & & $-|34|$ \\
\hline GABPB2 & -13 & V\$CREL_0I & & -145 \\
\hline GOS2 & -1832 & V\$CREL_0I & & -1914 \\
\hline IGFBP5 & -176 & & V\$NFKAPPAB_0I & -135 \\
\hline \multirow[t]{2}{*}{$I L 7 R$} & -184 (II) & & V\$NFKB_C & -184 \\
\hline & $-2348(I)$ & V\$NFKAPPAB65_0I & V\$NFKAPPAB_0I & -2344 \\
\hline \multirow[t]{2}{*}{ MAT2A } & -343 (II) & & V\$NFKAPPAB_0I & -312 \\
\hline & $-1249(I)$ & V\$CREL_0I & & -1248 \\
\hline \multirow[t]{3}{*}{ PLAU } & -1598 & V\$CREL_0I & & -1942 \\
\hline & -1838 & & V\$NFKAPPAB65_0I & \\
\hline & -1872 & V\$NFKAPPAB65_0I & V\$NFKAPPAB_0I & \\
\hline PTX3 & -64 & V\$NFKAPPAB_0I & V\$NFKAPPAB_0I & -147 \\
\hline RGS20 & -179 & & V\$NFKAPPAB_0I & -345 \\
\hline STC2 & -642 & & V\$NFKAPPAB65_0I & -587 \\
\hline TNFRSFI I B/osteoprotegerin & -128 & V\$CREL_0I & & -258 \\
\hline
\end{tabular}

The predicted NFKB binding sites that were confirmed by chromatin immunoprecipitation are indicated by the most 5 ' nucleotide. When multiple matrices predicted overlapping sites, the position indicates the most 5 ' nucleotide of the consensus sequence (see Additional file 4 for all sequences). Both over-represented (Table 4) and 7 additional (Additional file 4) NFKB matrices were used for the predictions. The TRANSFAC matrices shown are those that predicted the indicated sites with the lowest $p$-values. ChIP assays were considered to confirm binding sites located within $500 \mathrm{bp}$ of the primer position. The site in the promoter region of GABPB2 was predicted using the alignment of the hgl7 and mm5 genomes. Multiple binding sites for a gene are designated I and II, where appropriate. Primer positions are indicated by the most $5^{\prime}$ nucleotide of the forward primer; all amplicons were $50-55$ bp. 

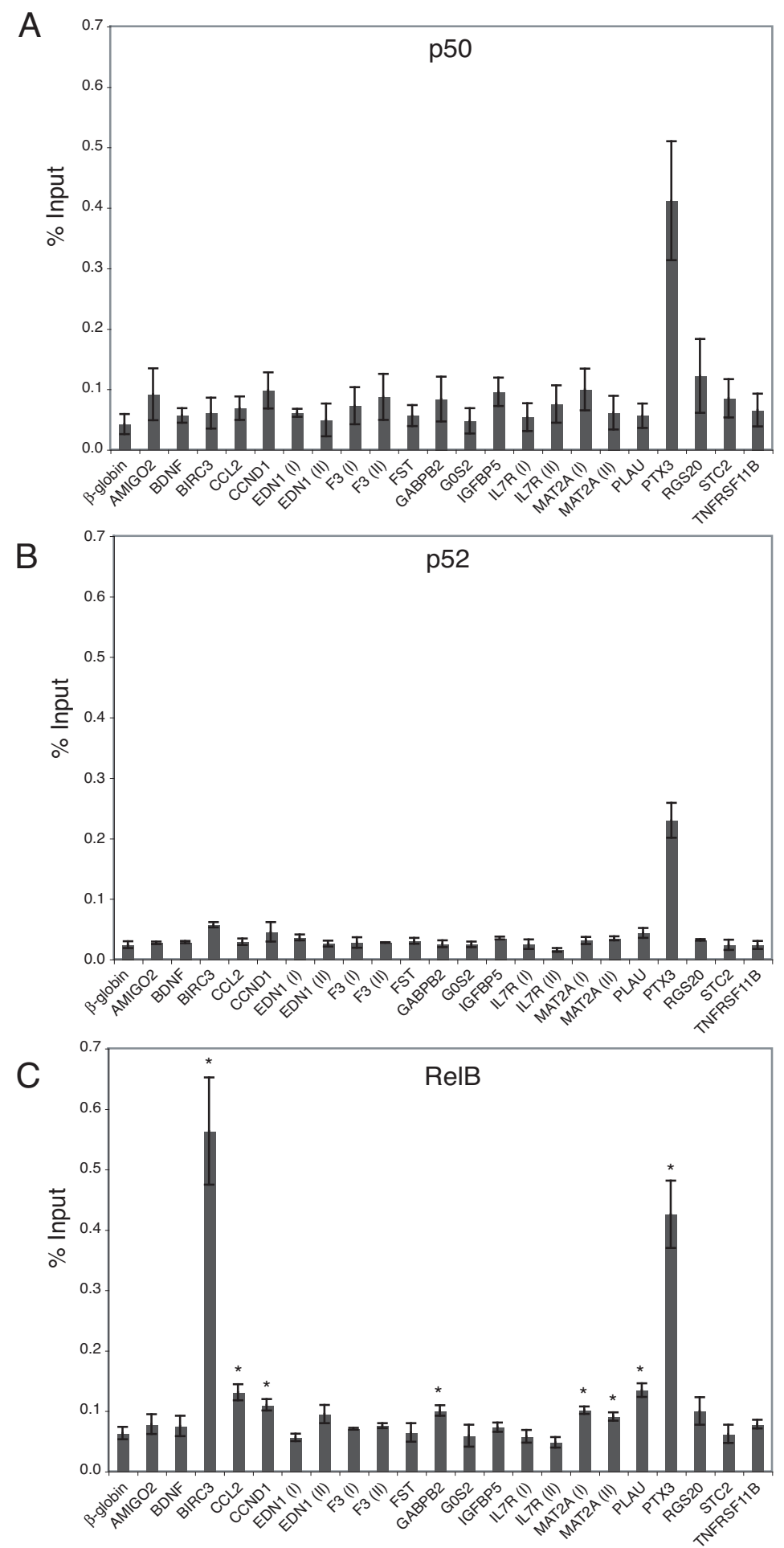

Figure 6

Analysis of NF $\kappa B$ binding sites in proliferating cells by chromatin immunoprecipitation. Chromatin fragments from proliferating T98G cells were immunoprecipitated with either anti-p50 (A), anti-p52 (B), or anti-RelB $(C)$ antibody and quantified by real-time PCR. Data are presented as the percentage of input and are the means of 2 independent experiments with anti-p50 and anti-p52 or 3 independent experiments with anti-RelB \pm S.E. $\beta$-globin was used as the negative control. In panel $C,(*)$ represents statistically significant binding compared to $\beta$-globin (assessed by $t$-test). 


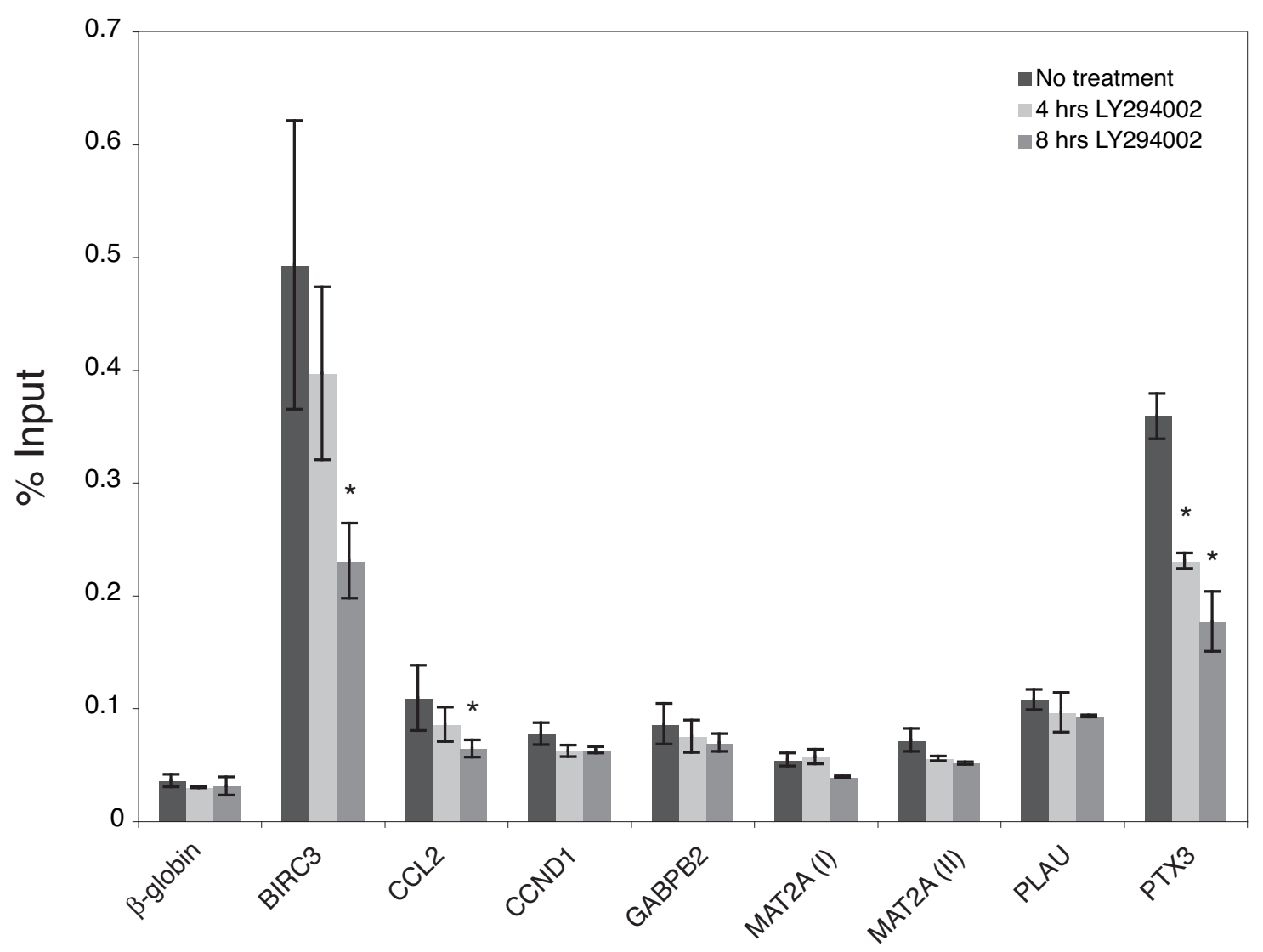

Figure 7

PI 3-kinase inhibition causes a decrease in RelB binding. T98G cells were either maintained in serum or treated with 50 $\mu M$ LY294002 for 4 or 8 hours. Chromatin fragments were immunoprecipitated with anti-RelB antibody and quantified by realtime PCR. Data are presented as the percentage of input and are the means of 3 independent experiments \pm S.E. $\beta$-globin was used as the negative control. $(*)$ represents statistically significant loss of binding compared to the cells maintained in serum (assessed by $t$ test).

We also compared the genes affected by PI 3-kinase inhibition with the genes identified in a recent study of the effects of mitogen withdrawal on gene expression in proliferating human fibroblasts [65]. In these experiments, primary fetal human lung fibroblasts were cultured in the presence of a low concentration of serum, IGF-1 and PDGF, and were growth-arrested by withdrawal of PDGF, which resulted in the entry of cells into $\mathrm{G}_{0}$; however, in contrast to our experiments, no significant increase in cells undergoing apoptosis was observed. This entry of cells into quiescence rather than apoptosis is consistent with the continued presence of low concentrations of serum and IGF-1 in the experiments of Coller et al [65], in contrast to the complete inhibition of PI 3-kinase in our studies. Comparing these two studies indicated that very little overlap exists between the genes regulated by inhibition of PI 3-kinase signaling and those regulated by 14 hours or 4 days of PDGF withdrawal. However, most of the overlapping genes, including CCNG2, PLAU, BDNF, and FGF2, and a number of non-overlapping genes regulated by mitogen withdrawal have been connected to the regulation of cell proliferation. Thus, there are functional overlaps in the genes regulated by PI 3-kinase inhibition and mitogen withdrawal, although they are clearly distinct gene sets as might be expected from the differences in treatments and their distinct effects on proliferation and apoptosis. We note that asynchronous cells were used in our study, and that similar analyses of synchronized cells might reveal PI 3-kinase regulation of distinct subsets or additional genes during specific stages of the cell cycle.

We have previously used computational analysis to identify transcription factor binding sites that are over-represented in promoter regions of immediate-early genes, including those regulated by PI 3-kinase signaling $[26,30,44]$. The transcription factors and families 
involved in regulation of these genes included CREB, SRF, FOXO and NFкB. We applied a similar analysis to the gene sets affected by inhibition of PI 3-kinase signaling in the present study. This revealed over-representation of phylogenetically conserved binding sites for FOXO and NFKB upstream of the genes that were up- and down-regulated, respectively, following 2 and 4 hours of PI 3kinase inhibition. Many of the predicted FOXO and NFKB binding sites were confirmed by ChIP, indicating that the FOXO and NFKB transcription factors play major roles in the transcriptional response to PI 3-kinase inhibition. This is consistent with the established regulation of these transcription factors by PI 3-kinase/Akt signaling, which inhibits FOXO and promotes NFKB activity $[16,19,20]$. Since p53 is also a major target of PI 3-kinase/Akt signaling in control of cell proliferation and survival $[12,13]$, we might have expected to similarly observe an over-representation of p53 binding sites. However, p53 is inactivated by mutation in T98G cells $[66,67]$, accounting for its absence in the gene sets analyzed in our experiments.

In total, we identified FOXO and NFKB binding sites upstream of about one-third of the genes that were upand down-regulated, respectively, by inhibition of PI 3kinase. Since our computational predictions of transcription factor binding sites were limited to phylogenetically conserved sites in promoter regions, this may be an underestimate of the total fraction of PI 3-kinase regulated genes that are targeted by these transcription factors. In particular, additional genes may be regulated by FOXO or NFKB binding sites in enhancers rather than promoter sequences, or by sites that were not conserved in the mouse. Other genes may be regulated at the transcriptional level by other transcription factors (such as Myc/ Max) or by non-transcriptional mechanisms, including regulation of mRNA decay [27].

Two members of the FOXO family (FOXO1 and 3a) were expressed in T98G cells and, as expected, both were activated in response to PI 3-kinase inhibition. In contrast, there are 5 members of the NFkB family (p65, c-Rel, RelB, p50 and p52), which can be activated by either the canonical or non-canonical pathways, both of which are stimulated by Akt $[19,20,64,68-70])$. We initially demonstrated binding of p65 to predicted NFKB sites following stimulation of the canonical pathway by TNFa. In unstimulated cells growing in the presence of serum however, only binding of p50, p52 and RelB was detected by ChIP, indicating that just the non-canonical pathway was active. Of these three family members, RelB is the main effector of this pathway, as it is the only one that contains a transactivation domain. Since the binding of RelB to promoters of down-regulated genes decreased following inhibition of PI 3-kinase, it appears that PI 3-kinase signaling regu- lates the non-canonical pathway of NFKB activation in proliferating cells.

The 10 genes identified as targets of FOXO and the 18 identified as targets of NFKB are summarized in Table 7. Binding sites for FOXO had been previously identified upstream of 4 of these genes, and new sites were identified upstream of 6 genes in the present study. Similarly, the 22 $\mathrm{NF \kappa B}$ binding sites identified upstream of 18 genes included 10 that were previously known, 5 that were newly identified in genes previously known to be regu-

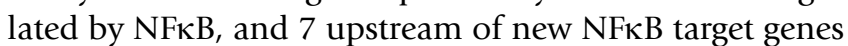
identified in the present study. It is noteworthy that nearly half of the FOXO and NFKB target genes whose expression is altered in response to inhibition of PI 3-kinase are known to function as regulators of apoptosis, including the previously unrecognized FOXO targets DDIT3/CHOP and TXNIP and the NFKB targets AMIGO2, BDNF, IGFBP5, and TNFRSF11B/osteoprotegerin. The predominant functions of these PI 3-kinase regulated genes emphasize the critical role of PI 3-kinase/Akt regulation of the FOXO and NFKB transcription factors in maintaining cell survival.

\section{Conclusion}

PI 3-kinase signaling in proliferating cells regulates a novel program of gene expression, which is distinct from that induced by growth factor stimulation of quiescent cells. The expression program controlled by continuous PI 3-kinase signaling in proliferating cells is enriched in genes that regulate cell survival and is mediated in large part by FOXO and RelB transcription factors.

\section{Methods \\ Cell Culture and RNA Extraction}

T98G human glioblastoma cells were grown in Minimal Essential Medium (Invitrogen) containing 10\% fetal bovine serum (HyClone) and 100 units/ml of penicillin/ streptomycin (Invitrogen). U937 cells were grown in RPMI 1640 (Cellgro) containing 10\% fetal bovine serum (HyClone). For LY294002 treatments, T98G cells were plated at $2 \times 10^{6}$ cells per $150 \mathrm{~mm}$ plate or $8 \times 10^{5}$ cells per $100 \mathrm{~mm}$ plate and U937 cells at $3 \times 10^{6}$ cells per $25 \mathrm{~cm}$ flask. T98G cells were cultured for 48 hours and U937 cells for 24 hours, at which time they were actively proliferating with a doubling time of approximately 20 hours. LY294002 (Biomol) was added to a final concentration of $50 \mu \mathrm{M}$. Wortmannin (Biomol) was added to a final concentration of $50 \mathrm{nM}$. Culturing of cells for serum starvation and subsequent treatments with either PDGF-BB (50 $\mathrm{ng} / \mathrm{ml}$ ) or $20 \%$ serum were carried out as previously described [44]. 
Table 7: FOXO and NF $\kappa$ B regulated genes.

\begin{tabular}{|c|c|c|c|c|c|}
\hline & Growth Factor/Receptor or Cytokine & Transcription & Proliferation & Apoptosis & References \\
\hline \multicolumn{6}{|c|}{ FOXO Target Genes } \\
\hline ATROGIN-I & & & & & [5I $]$ \\
\hline BCL6 & & + & & + & {$[49,50,80]$} \\
\hline BTGI & & & + & & {$[48,81]$} \\
\hline CCNG2 & & & + & & {$[41,46,47]$} \\
\hline DDIT3/CHOP & & + & + & + & {$[36,82]$} \\
\hline \multicolumn{6}{|l|}{ KIFIB } \\
\hline KLF6 & & + & + & & [83] \\
\hline \multicolumn{6}{|l|}{ KLHL24 } \\
\hline TXNIP & & & & + & {$[84]$} \\
\hline \multicolumn{6}{|l|}{ ZBTBI } \\
\hline \multicolumn{6}{|c|}{ NF $\kappa$ B Target Genes } \\
\hline AMIGO2 & & & & + & [85] \\
\hline BDNF & + & & + & + & [86] \\
\hline$B I R C 3 / c I A P 2$ & & & & + & {$[54,87]$} \\
\hline CCL2 & + & & & + & {$[55,88]$} \\
\hline CCNDI & & & + & & [56] \\
\hline EDN/-site I & + & & + & + & {$[57,89,90]$} \\
\hline EDN/-site II & + & & + & + & {$[89,90]$} \\
\hline \multicolumn{6}{|l|}{ F3-site I } \\
\hline F3-site II & & & & & [58] \\
\hline FST & + & & + & & [91] \\
\hline GOS2 & & & + & & [92] \\
\hline GABPB2 & & & & & [53] \\
\hline IGFBP5 & + & & + & + & {$[93,94]$} \\
\hline IL7R-site II & + & & + & + & {$[59,95]$} \\
\hline IL7R-site I & + & & + & + & [95] \\
\hline
\end{tabular}


Table 7: FOXO and NFאB regulated genes. (Continued)

\begin{tabular}{|c|c|c|c|}
\hline MAT2A-site II & & & {$[60]$} \\
\hline PLAU & + & + & {$[61,96]$} \\
\hline РТХЗ & & & [62] \\
\hline \multicolumn{4}{|l|}{ RGS20 } \\
\hline \multicolumn{4}{|l|}{ STC2 } \\
\hline TNFRSFI I B/osteoprotegerin & & + & {$[40]$} \\
\hline
\end{tabular}

All PI 3-kinase regulated genes containing upstream binding sites for either FOXO or NFKB are listed. Genes containing a previously reported FOXO or NFKB binding site, and the relevant reference, are in bold. The biological activity of each gene, as it pertains to growth factor/receptor or cytokine, transcription, proliferation, and apoptosis, is indicated along with references for these activities.

\section{Apoptosis Assays}

Apoptosis was assayed by DNA fragmentation and TUNEL staining as previously described [71].

\section{Immunoblot}

Enriched cytosolic and nuclear fractions were isolated from normal growing T98G cells as described elsewhere [72]. Proteins were separated by electrophoresis in $8 \%$ or $12 \%$ SDS-polyacrylamide gels, electroblotted to polyvinylidene difluoride membranes (PerkinElmer), and immunoblotted with anti-phospho Akt (Cell Signaling 9271), pan-anti-Akt (Cell Signaling 9272), anti-FOXO3a (Upstate 07-702), anti-FOX01 (Santa Cruz sc-11350), anti-FOXO4 (Santa Cruz sc-5221), anti-PARP (poly (ADP-ribose) polymerase) (Cell Signaling 9542), and anti-14-3-3 (Upstate 06-511) as recommended by the manufacturer. The immunoblots were visualized using goat anti-rabbit or rabbit anti-goat horseradish peroxidase-linked secondary antibodies (Bio-Rad) and chemiluminescence (PerkinElmer). Densitometry was performed using IQMac v1.2 software (Molecular Dynamics, Sunnyvale,

CA).

\section{Microarray Analysis}

Microarray spotting, sample preparation, hybridization, image analysis and data analysis were performed as previously described [44]. Microarrays were spotted with 21,329 70-mer oligonucleotides from Operon's Human Genome Array-Ready Oligo Set Version 2.0. RNA for microarray experiments was extracted with TRIzol reagent (Invitrogen) followed by poly(A)+ RNA isolation with an Oligotex mRNA Midi Kit (Qiagen) according to each manufacturer's protocol. Microarrays were performed with three independent biological samples. Dye-swap, background-subtracted median intensity values were used as input to the LIMMA analysis package [73] in Bioconductor [74], and average LOESS-corrected $\log _{2}$ ratios were used to estimate differential gene expression after LY294002 treatment. Differentially expressed genes were those with a change in expression greater than or equal to 1.87 fold $\left(\log _{2} 0.9\right)$ relative to untreated samples and false discovery rate (FDR)-corrected [75] moderated $t$-test $p$-values less than 0.01 .

\section{Real-time reverse transcription-polymerase chain reaction (RT-PCR)}

Real-time RT-PCR was carried out as previously described on RNA samples isolated from either T98G cells or U937 cells treated with LY294002 for 4 hours [26].

\section{Gene Ontology Analysis}

Gene Ontology (GO) terms were obtained using the webbased tool GOstat [76]. The genes that were either up- or down-regulated following 2 and 4 hours of PI 3-kinase inhibition were independently analyzed from the genes that were either up- or down-regulated following 8 hours of PI 3-kinase inhibition. Enrichment of GO categories was determined by comparing the terms associated with the differentially regulated genes to the terms associated with all genes on the array using a Fisher's exact test. Only genes annotated with at least 1 term were included in the analysis. Results were limited to the GO categories that were associated with at least $15 \%$ of the genes, with $p<$ 0.001 .

\section{Transcription Factor Binding Site Analysis}

Over-representation of transcription factor binding sites in the upstream regions of genes that were differentially expressed in response to inhibition of PI 3-kinase was determined as previously described $[26,30,44]$. The genes that were either up- or down-regulated following 2 and 4 hours of PI 3-kinase inhibition were independently analyzed from the genes that were either up- or down-regulated following 8 hours of PI 3-kinase inhibition. The regions $3 \mathrm{~kb}$ upstream of transcription start sites in the human and the corresponding mouse orthologous sequences were analyzed with the Match program using the MinSUM threshold [77], and both the 548 vertebrate 
position weight matrices from TRANSFAC Professional version 8.4 and the 588 matrices from TRANSFAC version 11.1 [78]. Sequences and MULTIZ alignments were obtained from the University of California Santa Cruz Genome Browser (human version hg18, mouse version mm8) [79], which were available for 28 of the 32 up-regulated genes and for 48 of the 53 down-regulated genes. For each matrix, a permutation test was used to compare the frequencies of the predicted sites in the differentially expressed gene set to the frequencies of the predicted sites in a background set of 662 genes that were expressed but did not change expression upon PI 3-kinase inhibition (average $\log _{2}$ ratios between -0.01 and 0.01 ). P-values were FDR-corrected to adjust for multiple testing [75].

\section{Flag-FOXO3a-AAA Chromatin Immunoprecipitations}

T98G cells were plated at $4 \times 10^{5}$ cells per $100 \mathrm{~mm}$ plate in complete media 24 hours before transfection. TransIT (Mirus Bio) reagent was used to transfect $8 \mu \mathrm{g}$ of either pcDNA3 (Invitrogen) or pcDNA3-Flag-FOXO3a-AAA [Addgene plasmid 10709, provided by Dr. William R. Sellers [46]], as recommended by the manufacturer. 24 hours after transfection 3 identical plates were harvested and ChIP assays were performed as previously described [30] except that chromatin was immunoprecipitated overnight at $4^{\circ} \mathrm{C}$ using $10 \mu \mathrm{g}$ of anti-M5-Flag (Sigma F4042) antibody and Protein $\mathrm{G}$ agarose beads (Upstate). Protein $G$ agarose beads were washed successively in low salt wash, high salt wash, $\mathrm{LiCl}$ wash and twice in 1xTE. Immunoprecipitated chromatin was quantified with real-time PCR using primers designed within 250 bp of the predicted transcription factor binding sites.

\section{NF $\kappa$ B Chromatin Immunoprecipitations}

For treatment with TNF $\alpha$, T98G cells were plated at $8 \times$ $10^{5}$ cells per $100 \mathrm{~mm}$ plate in complete media 48 hours before treatment. Cells were then either left untreated, or treated with $20 \mu \mathrm{g} / \mathrm{ml}$ of TNF $\alpha$ (R \& D Systems) for 0.25 , 0.5 or 1 hour. For experiments using unstimulated cells, T98G cells were plated at $2 \times 10^{6}$ cells per $150 \mathrm{~mm}$ plate, and ChIP assays performed 48 hours after plating. When indicated, cells were treated with $50 \mu \mathrm{M}$ LY294002 for 4 or 8 hours. ChIP assays were performed as previously described [30], except that either $5 \mu \mathrm{g}$ of p 65 antibody, cRel antibody, p50 antibody, RelB antibody (Santa Cruz Biotechnology, sc-372, sc-71, sc-114, sc-226), or $5 \mu \mathrm{l}$ of p52 antibody (Upstate, 06-413) was used for the immunoprecipitations. Protein A agarose beads were washed successively in low salt wash, high salt wash, $\mathrm{LiCl}$ wash and twice in 1xTE. Immunoprecipitated chromatin was quantified by real-time PCR using primers that were located within $320 \mathrm{bp}$ of the predicted binding site.

\section{Authors' contributions}

JT and JRG contributed equally to all aspects of the study, JWT contributed to the overall study design and experimental analysis of FOXO activation, KWA to analysis of apoptosis following PI 3-kinase inhibition, MES to analysis of the microarray data, and GMC to conception and analysis of the study. JT, JRG, and GMC were primarily responsible for preparation of the manuscript, with critical comments and revisions from MES and JWT. All authors read and approved the final manuscript.

\section{Additional material}

\author{
Additional file 1 \\ Expression changes arising after 2, 4, and 8 hours of PI 3-kinase inhibi- \\ tion \\ Click here for file \\ [http://www.biomedcentral.com/content/supplementary/1471- \\ 2121-9-6-S1.xls]
}

\section{Additional file 2}

Effects of LY294002 and wortmannin on gene expression Click here for file

[http://www.biomedcentral.com/content/supplementary/14712121-9-6-S2.pdf]

\section{Additional file 3}

TRANSFAC matrices tested for over-representation in the genes that were differentially expressed after 2 and 4 hours of PI 3-kinase inhibition Click here for file

[http://www.biomedcentral.com/content/supplementary/14712121-9-6-S3.xls]

\section{Additional file 4}

Predicted FOXO and NFKB binding sites in the genes that were either upor down-regulated after PI 3-kinase inhibition

Click here for file

[http://www.biomedcentral.com/content/supplementary/14712121-9-6-S4.xls]

\section{Acknowledgements}

We are grateful to Ulla Hansen for helpful discussions and critical comments on the manuscript. This work was supported by NIH grant ROI CAI8689.

\section{References}

I. Cantley LC: The phosphoinositide 3-kinase pathway. Science 2002, 296(5573): 1655-1657.

2. Datta SR, Brunet A, Greenberg ME: Cellular survival: a play in three Akts. Genes Dev 1999, 13(22):2905-2927.

3. Datta SR, Dudek H, Tao X, Masters S, Fu H, Gotoh Y, Greenberg ME: Akt phosphorylation of BAD couples survival signals to the cell-intrinsic death machinery. Cell I997, 9 I(2):23I-24I.

4. del Peso L, Gonzalez-Garcia M, Page C, Herrera R, Nunez G: Interleukin-3-induced phosphorylation of BAD through the protein kinase Akt. Science 1997, 278(5338):687-689.

5. Cross DA, Alessi DR, Cohen P, Andjelkovich M, Hemmings BA: Inhibition of glycogen synthase kinase-3 by insulin mediated by protein kinase B. Nature 1995, 378(6559):785-789. 
6. Pap M, Cooper GM: Role of glycogen synthase kinase-3 in the phosphatidylinositol 3-Kinase/Akt cell survival pathway. J Biol Chem 1998, 273(32): 19929-19932.

7. Maurer U, Charvet C, Wagman AS, Dejardin E, Green DR: Glycogen synthase kinase- 3 regulates mitochondrial outer membrane permeabilization and apoptosis by destabilization of MCL-I. Mol Cell 2006, 2 I(6):749-760.

8. Diehl JA, Cheng M, Roussel MF, Sherr CJ: Glycogen synthase kinase-3 $\beta$ regulates cyclin DI proteolysis and subcellular localization. Genes Dev 1998, I 2(22):3499-35I I.

9. Pap M, Cooper GM: Role of translation initiation factor $\mathbf{2 B}$ in control of cell survival by the phosphatidylinositol 3-kinase Akt/glycogen synthase kinase $3 \beta$ signaling pathway. Mol Cell Biol 2002, 22(2):578-586.

10. Doble BW, Woodgett JR: GSK-3: tricks of the trade for a multitasking kinase. J Cell Sci 2003, I I 6(Pt 7): I I75- I I86.

II. Jope RS, Johnson GV: The glamour and gloom of glycogen synthase kinase-3. Trends Biochem Sci 2004, 29(2):95-102.

12. Brazil DP, Hemmings BA: Ten years of protein kinase $B$ signalling: a hard Akt to follow. Trends Biochem Sci 200I, 26(I I):657-664.

13. Brazil DP, Yang ZZ, Hemmings BA: Advances in protein kinase B signalling: AKTion on multiple fronts. Trends Biochem Sci 2004, 29(5):233-242.

14. Brunet A, Bonni A, Zigmond MJ, Lin MZ, Juo P, Hu LS, Anderson MJ, Arden KC, Blenis J, Greenberg ME: Akt promotes cell survival by phosphorylating and inhibiting a Forkhead transcription factor. Cell I 999, 96(6):857-868.

15. Kops G], de Ruiter ND, De Vries-Smits AM, Powell DR, Bos JL, Burgering BM: Direct control of the Forkhead transcription factor AFX by protein kinase B. Nature 1999, 398(6728):630-634.

16. van der Horst A, Burgering BM: Stressing the role of FoxO proteins in lifespan and disease. Nat Rev Mol Cell Biol 2007, 8(6):440-450

17. Mayo LD, Donner DB: A phosphatidylinositol 3-kinase/Akt pathway promotes translocation of $\mathrm{Mdm} 2$ from the cytoplasm to the nucleus. Proc Natl Acad Sci U S A 200I, 98(20): I| $598-1 \mid 603$.

18. Basu S, Totty NF, Irwin MS, Sudol M, Downward J: Akt phosphorylates the Yes-associated protein, YAP, to induce interaction with 14-3-3 and attenuation of p73-mediated apoptosis. Mol Cell 2003, I I(I): I I-23.

19. Romashkova JA, Makarov SS: NF-KB is a target of AKT in antiapoptotic PDGF signalling. Nature I999, 40I(6748):86-90.

20. Ozes ON, Mayo LD, Gustin JA, Pfeffer SR, Pfeffer LM, Donner DB NF- $\kappa B$ activation by tumour necrosis factor requires the Akt serine-threonine kinase. Nature 1999, 40 I(6748):82-85.

21. Du K, Montminy M: CREB is a regulatory target for the protein kinase Akt/PKB. J Biol Chem 1998, 273(49):32377-32379.

22. Grimes CA, Jope RS: CREB DNA binding activity is inhibited by glycogen synthase kinase- $3 \beta$ and facilitated by lithium. J Neurochem 200I, 78(6): I219-1232.

23. Pulverer BJ, Fisher C, Vousden K, Littlewood T, Evan G, Woodgett JR: Site-specific modulation of c-Myc cotransformation by residues phosphorylated in vivo. Oncogene 1994, 9(1):59-70.

24. Lutterbach B, Hann SR: Hierarchical phosphorylation at $\mathbf{N}$-terminal transformation-sensitive sites in c-Myc protein is regulated by mitogens and in mitosis. Mol Cell Biol 1994, I 4(8):55I0-5522.

25. Boyle WJ, Smeal T, Defize LH, Angel P, Woodgett JR, Karin M, Hunter T: Activation of protein kinase $C$ decreases phosphorylation of c-Jun at sites that negatively regulate its DNA binding activity. Cell 199I, 64(3):573-584.

26. Tullai JW, Schaffer ME, Mullenbrock S, Kasif S, Cooper GM: Identification of transcription factor binding sites upstream of human genes regulated by the phosphatidylinositol 3-kinase and MEK/ERK signaling pathways. I Biol Chem 2004, 279(19):20167-20177.

27. Bromann PA, Korkaya H, Webb CP, Miller J, Calvin TL, Courtneidge SA: Platelet-derived growth factor stimulates Src-dependent mRNA stabilization of specific early genes in fibroblasts. J Biol Chem 2005, 280(I I): 10253-10263.

28. Demoulin JB, Ericsson J, Kallin A, Rorsman C, Ronnstrand L, Heldin $\mathrm{CH}$ : Platelet-derived growth factor stimulates membrane lipid synthesis through activation of phosphatidylinositol 3. kinase and sterol regulatory element-binding proteins. I Biol Chem 2004, 279(34):35392-35402.

29. Gu J, lyer VR: PI3K signaling and miRNA expression during the response of quiescent human fibroblasts to distinct proliferative stimuli. Genome Biol 2006, 7(5):R42.

30. Tullai JW, Chen J, Schaffer ME, Kamenetsky E, Kasif S, Cooper GM: Glycogen synthase kinase-3 represses cyclic AMP response element-binding protein (CREB)-targeted immediate early genes in quiescent cells. J Biol Chem 2007, 282(I3):9482-949I.

31. Yao R, Cooper GM: Growth factor-dependent survival of rodent fibroblasts requires phosphatidylinositol 3-kinase but is independent of pp70S6K activity. Oncogene 1996, I3(2):343-35I.

32. Takahashi Y, Rayman JB, Dynlacht BD: Analysis of promoter binding by the $E 2 F$ and $p R B$ families in vivo: distinct $E 2 F$ proteins mediate activation and repression. Genes Dev 2000, I4(7):804-8I6.

33. Stein GH: T98G: an anchorage-independent human tumor cell line that exhibits stationary phase $\mathbf{G I}$ arrest in vitro. J Cell Physiol 1979, 99(I):43-54

34. Vlahos C], Matter WF, Hui KY, Brown RF: A specific inhibitor of phosphatidylinositol 3-kinase, 2-(4-morpholinyl)-8-phenyl4H-I-benzopyran-4-one (LY294002). I Biol Chem 1994, 269(7):524|-5248

35. Knight ZA, Gonzalez B, Feldman ME, Zunder ER, Goldenberg DD, Williams O, Loewith R, Stokoe D, Balla A, Toth B, Balla T, Weiss WA Williams RL, Shokat KM: A pharmacological map of the PI3-K family defines a role for pI I $0 \alpha$ in insulin signaling. Cell 2006, I 25(4):733-747.

36. Oyadomari S, Mori M: Roles of CHOP/GADDI53 in endoplasmic reticulum stress. Cell Death Differ 2004, II (4):38I-389.

37. Selvakumaran M, Lin HK, Sjin RT, Reed JC, Liebermann DA, Hoffman $B$ : The novel primary response gene MyDII 8 and the protooncogenes myb, myc, and bcl-2 modulate transforming growth factor $\beta$ I-induced apoptosis of myeloid leukemia cells. Mol Cell Biol 1994, I4(4):2352-2360.

38. Hossain GS, van Thienen JV, Werstuck GH, Zhou J, Sood SK, Dickhout JG, de Koning AB, Tang D, Wu D, Falk E, Poddar R, Jacobsen DW, Zhang K, Kaufman RJ, Austin RC: TDAG5I is induced by homocysteine, promotes detachment-mediated programmed cell death, and contributes to the development of atherosclerosis in hyperhomocysteinemia. I Biol Chem 2003 278(32):30317-30327.

39. Wang CY, Mayo MW, Korneluk RG, Goeddel DV, Baldwin AS Jr.: NF- $K B$ antiapoptosis: induction of TRAFI and TRAF2 and $c-$ IAPI and c-IAP2 to suppress caspase-8 activation. Science 1998, 28 I(5383): | 680-| 683.

40. Emery JG, McDonnell P, Burke MB, Deen KC, Lyn S, Silverman C, Dul E, Appelbaum ER, Eichman C, DiPrinzio R, Dodds RA, James IE, Rosenberg M, Lee JC, Young PR: Osteoprotegerin is a receptor for the cytotoxic ligand TRAIL. I Biol Chem 1998, 273(23): 14363-14367

4I. Bennin DA, Don AS, Brake T, McKenzie JL, Rosenbaum H, Ortiz L, DePaoli-Roach AA, Horne MC: Cyclin G2 associates with protein phosphatase $2 A$ catalytic and regulatory B' subunits in active complexes and induces nuclear aberrations and a G II S phase cell cycle arrest. J Biol Chem 2002, 277(30):27449-27467.

42. Rouault JP, Rimokh R, Tessa C, Paranhos G, Ffrench M, Duret L, Garoccio M, Germain D, Samarut J, Magaud JP: BTGI, a member of a new family of antiproliferative genes. Embo J 1992, I I(4): 1663-1670

43. Zhan Q, Lord KA, Alamo I Jr., Hollander MC, Carrier F, Ron D, Kohn $\mathrm{KW}$, Hoffman B, Liebermann DA, Fornace AJ Jr.: The gadd and MyD genes define a novel set of mammalian genes encoding acidic proteins that synergistically suppress cell growth. Mol Cell Biol 1994, I4(4):2361-237I.

44. Tullai JW, Schaffer ME, Mullenbrock S, Sholder G, Kasif S, Cooper GM: Immediate-early and delayed primary response genes are distinct in function and genomic architecture. J Biol Chem 2007, 282(33):2398I-23995

45. Wasserman WW, Sandelin A: Applied bioinformatics for the identification of regulatory elements. Nat Rev Genet 2004, 5(4):276-287.

46. Ramaswamy S, Nakamura N, Sansal I, Bergeron L, Sellers WR: A novel mechanism of gene regulation and tumor suppression by the transcription factor FKHR. Cancer Cell 2002, 2(I):8I-9I. 
47. Martinez-Gac L, Marques M, Garcia Z, Campanero MR, Carrera AC Control of cyclin G2 mRNA expression by forkhead transcription factors: novel mechanism for cell cycle control by phosphoinositide 3-kinase and forkhead. Mol Cell Biol 2004, 24(5):218|-2।89.

48. Bakker WJ, Blazquez-Domingo M, Kolbus A, Besooyen J, Steinlein P, Beug $H$, Coffer PJ, Lowenberg B, von Lindern M, van Dijk TB FoxO3a regulates erythroid differentiation and induces BTGI, an activator of protein arginine methyl transferase $I$. J Cell Biol 2004, 164(2): I75-184.

49. Fernandez de Mattos S, Essafi A, Soeiro I, Pietersen AM, Birkenkamp KU, Edwards CS, Martino A, Nelson BH, Francis JM, Jones MC, Brosens JJ, Coffer PJ, Lam EW: FoxO3a and BCR-ABL regulate cyclin D2 transcription through a STAT5/BCL6-dependent mechanism. Mol Cell Biol 2004, 24(22): I0058-I007|.

50. Tang TT, Dowbenko D, Jackson A, Toney L, Lewin DA, Dent AL, Lasky LA: The forkhead transcription factor AFX activates apoptosis by induction of the BCL-6 transcriptional repressor. J Biol Chem 2002, 277( (16): I 4255-I 4265.

51. Sandri M, Sandri C, Gilbert A, Skurk C, Calabria E, Picard A, Walsh K, Schiaffino S, Lecker SH, Goldberg AL: Foxo transcription factors induce the atrophy-related ubiquitin ligase atrogin-I and cause skeletal muscle atrophy. Cell 2004, II 7(3):399-4I2.

52. Perkins ND: Integrating cell-signalling pathways with NF- $\kappa$ B and IKK function. Nat Rev Mol Cell Biol 2007, 8(I):49-62.

53. Schreiber J, Jenner RG, Murray HL, Gerber GK, Gifford DK, Young RA: Coordinated binding of NF- $K B$ family members in the response of human cells to lipopolysaccharide. Proc Natl Acad Sci U S A 2006, 103(15):5899-5904.

54. Hong SY, Yoon WH, Park JH, Kang SG, Ahn JH, Lee TH: Involvement of two NF- $\kappa$ B binding elements in tumor necrosis factor $\alpha$-, CD40-, and epstein-barr virus latent membrane protein I-mediated induction of the cellular inhibitor of apoptosis protein 2 gene. J Biol Chem 2000, 275(24): | 8022- $\mid 8028$.

55. Ueda A, Okuda K, Ohno S, Shirai A, Igarashi T, Matsunaga K, Fukushima J, Kawamoto S, Ishigatsubo Y, Okubo T: NF- $\mathrm{B}$ and SpI regulate transcription of the human monocyte chemoattractant protein-I gene. I Immunol 1994 I 53(5):2052-2063.

56. Guttridge DC, Albanese C, Reuther JY, Pestell RG, Baldwin AS Jr.: NF- $\kappa B$ controls cell growth and differentiation through transcriptional regulation of cyclin DI. Mol Cell Biol 1999, 19(8):5785-5799.

57. Quehenberger $P$, Bierhaus A, Fasching $P$, Muellner $C$, Klevesath $M$ Hong M, Stier G, Sattler M, Schleicher E, Speiser W, Nawroth PP: Endothelin I transcription is controlled by nuclear factor $-\kappa B$ in AGE-stimulated cultured endothelial cells. Diabetes 2000 , 49(9): $156 \mid-1570$.

58. Mackman N, Brand K, Edgington TS: Lipopolysaccharide-mediated transcriptional activation of the human tissue factor gene in THP-I monocytic cells requires both activator protein I and nuclear factor $\kappa$ B binding sites. J Exp Med |99|, I74(6): $15 \mid 7-1526$.

59. Tian B, Nowak DE, Jamaluddin M, Wang S, Brasier AR: Identification of direct genomic targets downstream of the nuclear factor $-\mathrm{K} B$ transcription factor mediating tumor necrosis factor signaling. / Biol Chem 2005, 280( I 7): I7435-I7448.

60. Yang H, Sadda MR, Yu V, Zeng Y, Lee TD, Ou X, Chen L, Lu SC: Induction of human methionine adenosyltransferase $2 A$ expression by tumor necrosis factor $\alpha$. Role of NF- $\kappa$ B and AP-I. J Biol Chem 2003, 278(5 I):50887-50896.

6I. Novak U, Cocks BG, Hamilton JA: A labile repressor acts through the NFkB-like binding sites of the human urokinase gene. Nucleic Acids Res 199I, 19(1 2):3389-3393.

62. Basile A, Sica A, d'Aniello E, Breviario F, Garrido G, Castellano M, Mantovani A, Introna M: Characterization of the promoter for the human long pentraxin PTX3. Role of NF- $K B$ in tumor necrosis factor- $\alpha$ and interleukin-I $\beta$ regulation. I Biol Chem 1997, 272(I3):8I72-8I78

63. Lipsky RH, Xu K, Zhu D, Kelly C, Terhakopian A, Novelli A, Marini AM: Nuclear factor $\kappa B$ is a critical determinant in N-methylD-aspartate receptor-mediated neuroprotection. I Neurochem 200I, 78(2):254-264.
64. Gustin JA, Korgaonkar CK, Pincheira R, Li Q, Donner DB: Akt regulates basal and induced processing of NF-KB2 (p I 00) to p52. J Biol Chem 2006, 28 I (24): I6473-I648I.

65. Coller HA, Sang L, Roberts JM: A new description of cellular quiescence. PLoS Biol 2006, 4(3):e83.

66. el-Deiry WS, Kern SE, Pietenpol JA, Kinzler KW, Vogelstein B: Definition of a consensus binding site for p53. Nat Genet 1992, I(I):45-49.

67. Davidoff AM, Kerns BJ, Iglehart JD, Marks JR: Maintenance of p53 alterations throughout breast cancer progression. Cancer Res I991, 5 I (10):2605-26I0

68. Madrid LV, Mayo MW, Reuther JY, Baldwin AS Jr. Akt stimulates the transactivation potential of the RelA/p65 Subunit of NF$\kappa B$ through utilization of the $I \kappa B$ kinase and activation of the mitogen-activated protein kinase p38. I Biol Chem 200I, 276(22): 18934-18940.

69. Madrid LV, Wang CY, Guttridge DC, Schottelius AJ, Baldwin AS Jr., Mayo MW: Akt suppresses apoptosis by stimulating the transactivation potential of the RelA/p65 subunit of NF-KB. Mol Cell Biol 2000, 20(5):1626-1638.

70. Sizemore N, Leung S, Stark GR: Activation of phosphatidylinositol 3-kinase in response to interleukin-I leads to phosphorylation and activation of the NF-kB p65/RelA subunit. Mol Cell Biol 1999, 19(7):4798-4805.

7I. Adams KW, Cooper GM: Rapid turnover of mcl-I couples translation to cell survival and apoptosis. I Biol Chem 2007 282(9):6192-6200

72. Meares GP, Jope RS: Resolution of the nuclear localization mechanism of glycogen synthase kinase-3: functional effects in apoptosis. J Biol Chem 2007, 282(23):16989-1700I.

73. Smyth GK: Limma: linear models for microarray data. In Bioinformatics and Computational Biology Solutions using $\mathbf{R}$ and Bioconductor. Gentleman, R., Carey, V., Dudoit, S., Irizarry, R., and Huber, W. (eds). New York, Springer; 2005:pp 397-420.

74. Gentleman RC, Carey VJ, Bates DM, Bolstad B, Dettling M, Dudoit S, Ellis B, Gautier L, Ge Y, Gentry J, Hornik K, Hothorn T, Huber W, lacus S, Irizarry R, Leisch F, Li C, Maechler M, Rossini AJ, Sawitzki G, Smith C, Smyth G, Tierney L, Yang JY, Zhang J: Bioconductor: open software development for computational biology and bioinformatics. Genome Biol 2004, 5(I 0):R80.

75. Benjamini $Y$ and Hochberg: Controlling the false discovery rate: a practical and powerful approach to multiple testing. J $R$ Statist Soc 1995, 57:289-300.

76. Beissbarth T, Speed TP: GOstat: find statistically overrepresented Gene Ontologies within a group of genes. Bioinformatics 2004, 20(9): | 464-1465.

77. Kel AE, Gossling E, Reuter I, Cheremushkin E, Kel-Margoulis OV, Wingender E: MATCH: A tool for searching transcription factor binding sites in DNA sequences. Nucleic Acids Res 2003 , 3 I ( I 3):3576-3579.

78. Matys V, Kel-Margoulis OV, Fricke E, Liebich I, Land S, Barre-Dirrie A, Reuter I, Chekmenev D, Krull M, Hornischer K, Voss N, Stegmaier $P$, Lewicki-Potapov B, Saxel $H$, Kel AE, Wingender E: TRANSFAC and its module TRANSCompel: transcriptional gene regulation in eukaryotes. Nucleic Acids Res 2006, 34(Database issue):DI08-10.

79. Kuhn RM, Karolchik D, Zweig AS, Trumbower H, Thomas DJ, Thakkapallayil A, Sugnet CW, Stanke M, Smith KE, Siepel A, Rosenbloom KR, Rhead B, Raney BJ, Pohl A, Pedersen JS, Hsu F, Hinrichs AS, Harte RA, Diekhans M, Clawson H, Bejerano G, Barber GP, Baertsch R, Haussler D, Kent W]: The UCSC genome browser database: update 2007. Nucleic Acids Res 2007, 35(Database issue): D668-73.

80. Albagli-Curiel O: Ambivalent role of BCL6 in cell survival and transformation. Oncogene 2003, 22(4):507-5I6.

8I. Matsuda S, Rouault J, Magaud J, Berthet C: In search of a function for the TIS2 I/PC3/BTGI/TOB family. FEBS Lett 200I, 497(23):67-72.

82. Barone MV, Crozat A, Tabaee A, Philipson L, Ron D: CHOP (GADDI53) and its oncogenic variant, TLS-CHOP, have opposing effects on the induction of GI/S arrest. Genes Dev 1994, 8(4):453-464.

83. Bieker J]: Kruppel-like factors: three fingers in many pies. J Biol Chem 200I, 276(37):34355-34358. 
84. Wang Z, Rong YP, Malone MH, Davis MC, Zhong F, Distelhorst CW: Thioredoxin-interacting protein (txnip) is a glucocorticoidregulated primary response gene involved in mediating glucocorticoid-induced apoptosis. Oncogene 2006, 25(13): 1903-1913.

85. Ono T, Sekino-Suzuki N, Kikkawa $Y$, Yonekawa H, Kawashima S: Alivin I, a novel neuronal activity-dependent gene, inhibits apoptosis and promotes survival of cerebellar granule neurons. J Neurosci 2003, 23(13):5887-5896.

86. Kalb R: The protean actions of neurotrophins and their receptors on the life and death of neurons. Trends Neurosci 2005, 28(I):5-II.

87. Liston P, Roy N, Tamai K, Lefebvre C, Baird S, Cherton-Horvat G, Farahani R, McLean M, lkeda JE, MacKenzie A, Korneluk RG: Suppression of apoptosis in mammalian cells by NAIP and a related family of IAP genes. Nature 1996, 379(6563):349-353.

88. Eugenin EA, D'Aversa TG, Lopez L, Calderon TM, Berman JW: MCP. I (CCL2) protects human neurons and astrocytes from NMDA or HIV-tat-induced apoptosis. I Neurochem 2003, 85(5):|299-|3||.

89. Alberts GF, Peifley KA, Johns A, Kleha JF, Winkles JA: Constitutive endothelin-I overexpression promotes smooth muscle cel proliferation via an external autocrine loop. J Biol Chem 1994 269(13): $10112-10118$.

90. Nelson JB, Udan MS, Guruli G, Pflug BR: Endothelin-I inhibits apoptosis in prostate cancer. Neoplasia 2005, 7(7):63|-637.

91. Cunningham MA, Zhu Q, Unterman TG, Hammond JM: Folliclestimulating hormone promotes nuclear exclusion of the forkhead transcription factor FoxO I a via phosphatidylinositol 3-kinase in porcine granulosa cells. Endocrinology 2003 I 44( ( 2):5585-5594.

92. Russell L, Forsdyke DR: A human putative lymphocyte G0/G I switch gene containing a CpG-rich island encodes a small basic protein with the potential to be phosphorylated. DNA Cell Biol I99I, I0(8):58I-59|.

93. Tanno B, Cesi V, Vitali R, Sesti F, Giuffrida ML, Mancini C, Calabretta $B$, Raschella G: Silencing of endogenous IGFBP-5 by micro RNA interference affects proliferation, apoptosis and differentiation of neuroblastoma cells. Cell Death Differ 2005, I 2(3):213-223.

94. Yin $\mathrm{P}, \mathrm{Xu} \mathrm{Q}$, Duan C: Paradoxical actions of endogenous and exogenous insulin-like growth factor-binding protein-5 revealed by RNA interference analysis. J Biol Chem 2004, 279(3 I):32660-32666.

95. Mazzucchelli R, Durum SK: Interleukin-7 receptor expression: intelligent design. Nat Rev Immunol 2007, 7(2): I 44-I54.

96. Pulukuri SM, Gondi CS, Lakka SS, Jutla A, Estes N, Gujrati M, Rao JS: RNA interference-directed knockdown of urokinase plasminogen activator and urokinase plasminogen activator receptor inhibits prostate cancer cell invasion, survival, and tumorigenicity in vivo. J Biol Chem 2005, 280(43):36529-36540.

Publish with Bio Med Central and every scientist can read your work free of charge

"BioMed Central will be the most significant development for disseminating the results of biomedical research in our lifetime. "

Sir Paul Nurse, Cancer Research UK

Your research papers will be:

- available free of charge to the entire biomedical community

- peer reviewed and published immediately upon acceptance

- cited in PubMed and archived on PubMed Central

- yours - you keep the copyright
BioMedcentral 